\title{
Facility Interface Capability Assessment (FICA) Summary Report
}

Date of Issue: May 1992

Prepared by

J. M. Viebrock and N. Mote

Nuclear Assurance Corporation

6251 Crooked Creek Road

Norcross, Georgia 30092

under

Subcontract 12X-97393C

Edited by

R. B. Pope

Oak Ridge National Laboratory

Oak Ridge, Tennessee 37831

managed by

Martin Marietta Energy Systems, Inc.

for the

U.S. Department of Energy

under contract DE-AC05-840R21400 


\section{Contents}

Page

Executive Summary $\ldots \ldots \ldots \ldots \ldots \ldots \ldots \ldots \ldots \ldots \ldots \ldots \ldots \ldots$ vii

Preface $\quad \ldots \ldots \ldots \ldots \ldots \ldots \ldots \ldots \ldots \ldots \ldots \ldots \ldots \ldots \ldots \ldots$ ix

1. Introduction $\ldots \ldots \ldots \ldots \ldots \ldots \ldots \ldots \ldots \ldots \ldots \ldots \ldots$

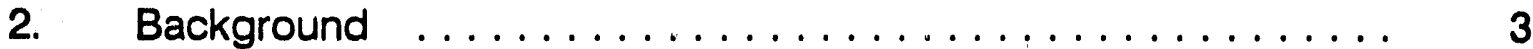

2.1 Overview ....................... 3

2.2 Project Scope ...................... 4

2.2.1. Phase I - Project Planning and Development ..... 4

2.2.2 Phase II - Site Visits and Data Assessment ... . . . 5

3. Technical Basis for the Project $\ldots \ldots \ldots \ldots \ldots \ldots \ldots \ldots \ldots$ 9

3.1 Fuel Assembly Dimensions . . . . . . . . . . . . . 9

3.2 Cask Parameters . . . . . . . . . . . . . . . . . 10

3.3 Facility Parameters ..................... 12

3.4 Operating Controls $\ldots \ldots \ldots \ldots \ldots \ldots \ldots \ldots \ldots \ldots$

4. FICA Project Results $\ldots \ldots \ldots \ldots \ldots \ldots \ldots \ldots \ldots \ldots \ldots$

4.1 Current Cask-Handling Limits . . . . . . . . . . . . . 19

4.1.1 Cask Diameter Limits ... . . . . . . . . . . . . . 20

4.1.2 Cask-Handling Capability Based on Cask Length .. 20

4.1.3 Cask Weight Limits ................. 21

4.1.4 Current Capability Using Combined Limits . . . . . . 22

4.2 Potential for Improved Cask-Handling Capabilities ....... 22

4.2.1 Potential for Improved LWT CaskHandling Capability ................. 24

4.2.2 Potential for Improved OWT CaskHandling Capability .................. 27

4.2.3 Potential for Improved 100-ton R/B CaskHandling Capability ............... 29

4.2.4 Potential for Improved 125-ton R/B CaskHandling Capability .................. 29

Appendix A. Summary of the Site Visit Program . . . . . . . . . . 33 


\section{List of Figures}

Figure

Page

1 Cask-handling dimension parameters $\ldots \ldots \ldots \ldots \ldots \ldots \ldots, 11$

2 Section view of generic PWR cask-handling facility $\ldots \ldots \ldots, 15$

$3 \quad$ Plan view of generic PWR cask-handling facility $\ldots \ldots \ldots \ldots, 16$

4 Section view of generic BWR cask-handling facility $\ldots \ldots \ldots, 17$

$5 \quad$ Plan view of generic BWR cask-handling facility $\ldots \ldots \ldots \ldots \ldots, 18$

6 Summary results of current and potential improved cask-handling capabilities ................ 25

7 Projected FICA LWT cask-handling capability $\ldots \ldots \ldots \ldots 26$

8 Projected FICA OWT LWT cask-handling capability .......... 28

$9 \quad$ Projected FICA 100-ton R/B cask-handling capability ....... 30

10 Projected FICA 125-ton R/B cask-handling capability . . . . . . 31 


\section{List of Tables}

Table

Page

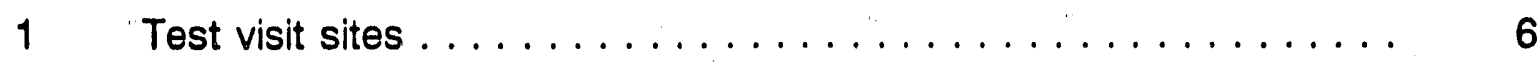

2 FICA Cask parameters $\ldots \ldots \ldots \ldots \ldots \ldots \ldots \ldots \ldots \ldots$

3 Effect of cask body diameter limitations on assessed cask-handling capability ..................... 20

4 Effect of cask length limitations on assessed cask-handling capability $\ldots \ldots \ldots \ldots \ldots \ldots \ldots \ldots \ldots \ldots \ldots \ldots$

5 Effect of cask weight limitations on assessed cask-handling capability $\ldots \ldots \ldots \ldots \ldots \ldots \ldots \ldots, 22$

6 Effects of combined cask length, diameter and weight limitations on assessed cask-handling capability ....... 23 


\section{Executive Summary}

The Office of Civilian Radioactive Waste Management (OCRWM) is responsible for developing the Civilian Radioartive Waste Management System (CRWMS) to accept spent nuclear fuel from commercial facilities. In support of the development of the CRWMS, OCRWM sponsored the Facility Interface Capability Assessment (FICA) project. The objective of this project was to assess the capability of each commercial facility to handle various spent nuclear fuel shipping casks.

The purpose of this report is to summarize the results of the facility assessments completed within the FICA project. The project was conducted in two phases. During Phase I, the data items required to complete the facility assessments were identified and the data base for the project was created. During Phase II, visits were made to 122 facilities on 76 sites to collect data and information, the data base was updated, and assessments of the cask-handling capabilities at each facility were performed.

Each assessment of cask-handling capability contains three parts:

1. the current capability of the facility (planning base),

2. the potential enhanced capability if revisions were made to the facility licensing and/or administrative controls, and

3. the potential enhanced capability if limited physical modifications were made to the facility.

Each assessment was completed using four conceptual cask size envelopes (dimensions and weights) that are referred to in this report as the "FICA Casks." The FICA Casks represent maximum bounds of casks that could be used as part of the CRWMS.

The main conclusion derived from the planning base assessments is that the current facility capabilities would not allow handling of any of the FICA Casks at 49 of the 122 facilities evaluated. However, consideration of potential revisions and/or modifications showed that all but one of the 122 facilities could be adapted to handle at least one of the FICA Casks. For this to be possible, facility licensing, administrative controls, and/or physical aspects of the facility would need to be modified.

The table below illustrates, in summary form, the results of the assessments, with and without potential actions to enhance cask handling capability. 
Assessment Summary - number of facilities able to handle the FICA Casks

\begin{tabular}{cccc}
\hline FICA Cask & $\begin{array}{c}\text { Number of facilities } \\
\text { capable of handling } \\
\text { casks based on } \\
\text { current capability }\end{array}$ & $\begin{array}{c}\text { capable of handling } \\
\text { casks following } \\
\text { administrative } \\
\text { and/or licensing } \\
\text { changes }\end{array}$ & $\begin{array}{c}\text { Number of facilities } \\
\text { capable of handling } \\
\text { casks following } \\
\text { administrative } \\
\text { changes, licensing } \\
\text { changes, and/or } \\
\text { plant modifications }\end{array}$ \\
\hline LWT & 73 & 105 & 121 \\
OWT & 68 & 98 & 119 \\
100-ton R/B & 50 & 76 & 99 \\
125-ton R/B & 26 & 52 & 79 \\
\hline
\end{tabular}

It is important to recognize that the project did not include any of the detailed technical analyses that would be required for implementing the potential changes identified. Therefore, there is no certainty that the assessed changes can be achieved. Demonstration that the potential changes could be achieved would have required technical analyses and the evaluation of licensing requirements that were beyond the scope of this project.

Nothing in this report is intended (1) to recommend judgment on whether any of the administrative changes, licensing changes or physical modifications considered should be completed; or (2) to imply that the utility or plant operator for any facility has expressed the intention of completing any facility changes. 


\section{Preface}

This report summarizes the results of the technical work completed in the FICA project. This project involved visits to, and the collection and analysis of data from, all 121 of the commercial nuclear reactors and one fuel storage facility (located at Morris, Illinois) from which spent fuel will be shipped to the Civilian Radioactive Waste Management System. During the visits, each facility's current cask-handling capability was determined, and the data collected were analyzed to assess the potential capability of that facility.

The technical data and follow-on detailed assessments relating to each facility's cask-handling capability are presented in the FICA Project Report. Copies of the FICA Project Report can be obtained, upon request to:

Office of Scientific and Technical Information

175 Oak Ridge Turnpike

Oak Ridge, TN 37830

In addition, individual facility assessment reports and a supporting data base were developed and can be obtained (in either hardcopy or electronic format on diskettes), upon request to:

TRW Environmental Safety Systems, Inc.

R. R. MacDonald

2650 Park Tower Drive

Suite 800

Vienna, VA 22180 


\section{Introduction}

The Nuclear Waste Policy Act (NWPA) of 1982, as amended, authorized the U.S. Department of Energy (DOE) to enter into contracts with owners and generators of spent nuclear fuel (SNF) and/or high-level radioactive waste (HLW) of domestic origin for acceptance of title to and subsequent transportation, storage, and disposal of such SNF and HLW. Under the provisions of the "Standard Contract for Disposal of Spent Nuclear Fuel and/or High-Level Radioactive Waste," (10 CFR 961) between DOE and owners (referred to as "Purchasers" in the contract), DOE is responsible for providing the shipping casks and all ancillary equipment needed for transporting these materials from the Purchasers' sites. The Purchasers will be responsible for loading the SNF into the transport casks.

The cask-handling capabilities that exist at Purchasers' reactors and other SNF storage facilities have an impact on the design of the Civilian Radioactive Waste Management System (CRWMS). To support the CRWMS design, especially that of the CRWMS transportation system, the DOE's Office of Civilian Radioactive Waste Management (OCRWM) determined that a facility interface capability assessment needed to be completed to determine facility capabilities for loading and shipping SNF. The assessment determined current capabilities, assessed limitations, and defined potential revisions to facility licensing and administrative controls, as well as potential limited physical facility modifications that might enhance facility capability to ship.

A primary source of information for this report has been the utilities and storage facility operators. Much of the information consisted of engineering drawings and technical documents provided in response to a written request. Visits to the 122 facilities on 76 sites that have contracts for delivering SNF to the DOE were also made to allow interpretation of the numerical data, discussion of any remaining data items, and verification of the data already obtained. The site visits provided an opportunity to walk through and visually assess the cask travel path, to examine the configuration and equipment associated with the SNF handling areas at each facility, and to hold discussions with facility operations and engineering staff. This process allowed examination of plant features that were not readily identifiable on drawings or in the documents provided by the utility. For example, in many cases, plant hardware or equipment extend into the cask travel path between the cask receiving area and the fuel loading area. However, because these items are above the floor level, they may not appear on the standard elevation drawings provided by utilities.

Following the initial data collection activity and completion of the site visit, an assessment was made of the existing capability of each site to ship SNF and the potential capability if the facility were to be modified. The purpose of this report is to summarize the results of the various assessments. 
The scope of the project did not include any of the detailed technical analyses that would be required for implementing the potential changes identified. Accordingly, the assessments are based only on the reviewer's judgment and engineering experience, and there is no certainty that the assessed changes can be, or should be, realized. Demonstration that the potential changes are achievable would have required technical analyses and the evaluation of licensing requirements that were beyond the scope of this project.

Nothing in this report is intended to recommend whether any of the administrative changes, licensing changes, or physical modifications considered should be completed. Finally, nothing in this report is intended to imply that the utility or plant operator for any facility has expressed the intention of completing any facility changes. 


\section{Background}

\subsection{OVERVIEW}

The Facility Interface Capability Assessment (FICA) project was performed to provide the data and analysis necessary to characterize the cask-handling interface capabilities between the CRWMS and the commercial facilities from which SNF will be shipped.

The specific objectives of the FICA project were to:

1. determine and document existing and planned facility capabilities to handle casks, and

2. identify facilities where possible interface changes could result in benefits to the shipping operations of the CRWMS by defining changes that might enhance the capability of the facility to ship SNF.

The FICA project was conducted in two phases. In Phase I, the informational requirements for performing assessments of facility capabilities were defined, a data base structure was produced for recording and presenting the information and data that would be obtained, and an Information Verification and Acquisition Plan (IVAP) was developed. The IVAP defined the procedure for performing site visits (data collecting) and assessments. In addition, site visit procedures were developed, ten nuclear reactors at five sites operated by five utilities were identified, and plans were made for visiting these sites at the beginning of Phase II so the IVAP and site visit procedures could be tested.

During Phase I, a FICA Utility Working Group was formed which consisted of representatives from the utilities operating the test visit facilities, the Electric Power Research Institute (EPRI) and the Edison Electric Institute (EEI/UWASTE).* The FICA Utility Working Group was established to facilitate communications with the Purchasers, coordinate visits, and facilitate Purchaser review of data ano project results. The FICA Utility Working Group was essential in providing a utility perspective to the project and, also, valuable guidance on how the visits could be completed without affecting the utilities' operational requirements.

In Phase II, site visits and assessments of facility interface capability were completed for the 22 commercial nuclear facilities on 76 sites from which SNF will be accepted by the CRWMS. The site visits included 121 reactors; in addition, a site visit was made to the storage facility at Morris Operations (formerly the General Electric Reprocessing Facility), which is located at Morris, Illinois.

*Utility Nuclear Waste and Transportation Program.

Facility Interface Capability Assessment (FICA) Summary Report 
In the performance of site visits during Phase II, discussions were held with and information obtained from utility staff representing operations, engineering and other departments. This ensured that the FICA information and data obtained during the site visits were current and accurate, it also increased the likelihood that the information and data were appropriately interpreted.

\subsection{PROJECT SCOPE}

\subsubsection{Phase I - Project Planning and Development}

Phase I of the FICA project began in 1986. The first task was the review of several existing data bases established to maintain information related to the cask-handling interfaces at existing power reactors and independent SNF storage facilities. In a parallel effort, the Energy Information Administration and OCRWM contractors and subcontractors were contacted to identify existing data requiring validation, as well as additional information that needed to be incorporated into the data base.

Following these actions, the FICA data base was created to accommodate those data items identified to meet the requirements of the project; then all available information and data were added. The result was a data base that summarized the information obtained through the review of existing data sources and identified the additional information that was required. The primary data sources used for this task were:

1. Fuel-Trac Data Base, Client Reports, and other internal sources - Nuclear Assurance Corporation, 1971-1986;

2. Control of Heavy Loads: Safety Evaluation Reports and Technical Evaluation Reports, NUREG-0612 (11 Volumes) - Franklin Research Center, 1981-1985;

3. Data Report on Sandia Document, Spent Nuclear Fuel and High-Level Waste Shipping Cask Interface Data Collection - Westinghouse Electric Corporation, September 17, 1986;

4. Spent Nuclear Fuel Shipping Cask Handling Capabilities of Commercial Light Water Reactors - Pacific Northwest Laboratory, April 1985; and

5. Information from the RW-859 Survey for INIS Data Base - Department of Energy - EIA, Electronic Transmittal (Magnetic Tape), March 1986.

The second task in Phase I was to develop a preliminary plan for the verification of information assembled in the first task, as well as a plan to acquire the data necessary to

Facility Interface Capability Assessment (FICA) Summary Report 
complete the data base. The latter plan, the IVAP, became the operation manual for the activities in Phase II. The IVAP documented the procedures for collecting the required information, including the site visits, and performing the facility assessments. Phase I was completed in December 1986.

\subsubsection{Phase II - Site Visits and Data Assessment}

The first task of Phase II included the completion of test visits to ten facilities at five selected sites in order to test the data base and the IVAP. The second task of Phase II included visiting the remainder of the facilities and performing assessments of all other facility cask-handling capabilities.

The ten facilities at the five sites included in the test visits are listed in Table 1. They were selected to reflect the range of reactor types [pressurized water reactor (PWR) and boiling water reactor (BWR)], vendors (General Electric, Westinghouse, Combustion Engineering, and Babcock \& Wilcox), spent-fuel shipping experience (none, limited, extensive), storage alternatives under consideration (e.g., in-pool and out-of-pool), plant age (1 to 17 years), and experience with fuels of different status (intact and failed) that would be encountered during the remainder of the site visits. On completion of the test visits (October 1987), draft assessments and facility data printouts were prepared.

In November 1987, the plan for the second task of Phase II was issued in preparation for visits to the remaining 71 sites ( 112 facilities). Throughout the performance of Phase II, the site visit schedule was periodically adjusted to meet utility availability. Visits to all sites were completed by March 1990. The facilities visited, along with the corresponding dates and locations, are shown in Appendix A. Throughout the site visits, a high level of utility cooperation and support was received.

During each site visit, an "open items list" was prepared and left with the utility to complete following the visit. This list identified the data that could not be obtained or verified during the site visit. Following each site visit, the data collected were entered into the project data base and a facility assessment report was completed. As the additional data became available, revisions to the facility assessment reports were made.

In order to provide a basis for assessing cask handling capabilities, generic casks were defined and are referred to in this report as "FICA Casks." The FICA Casks, which are described in more detail in Sect. 3.0, consisted of the following four generic models:

1. a legal-weight truck (LWT) cask,

2. an overweight truck (OWT) cask, 
Table 1. Test visit sites

\begin{tabular}{lllc}
\hline Facility & $\begin{array}{l}\text { Vendor/ } \\
\text { type }\end{array}$ & $\begin{array}{l}\text { Off-site } \\
\text { shipping } \\
\text { experience }\end{array}$ & $\begin{array}{c}\text { Initial year of } \\
\text { operation }\end{array}$ \\
\hline Millstone 1 & GE-BWR & None & 1970 \\
Millstone 2 & CE-PWR & None & 1975 \\
Millstone 3 & W-PWR & None & 1986 \\
Surry 1 & W-PWR & Extensive & 1972 \\
Surry 2 & W-PWR & Extensive & 1973 \\
Peach Bottom 2 & GE-BWR & Limited & 1974 \\
Peach Bottom 3 & GE-BWR & None & 1974 \\
St. Lucie 1 & CE-PWR & None & 1976 \\
St. Lucie 2 & CE-PW/R & None & 1983 \\
Crystal River 3 & B\&W-PWR & Limited & 1977 \\
\hline
\end{tabular}

'GE-BWR refers to a General Electric-supplied boiling water reactor plant; CE-PWR refers to a Combustion Engineering-supplied pressurized water reactor; W-PWR refers to a Westinghouse-supplied pressurized water reactor; and B\&W-PWR refers to a Babcock \& Wilcox-supplied pressurized water reactor. 
3. a 100-ton rail/barge (R/B) cask, and

4. a 125 -ton $\mathrm{R} / \mathrm{B}$ cask.

DOE is developing an LWT cask and a 100-ton R/B cask. The LWT and 100-ton R/B FICA Casks bound the dimensions and weight of these designs. The OWT and 125-ton R/B FICA Casks were based on earlier DOE concepts and on existing commercial casks.

Only weight and the external envelope dimensions were considered in defining the FICA Casks. Other aspects of suitability of the casks for SNF shipments from individual facilities (including the geometrical and radiological compatibility of the SNF with the cask design) were not included.

Each facility assessment first addressed the current capability of the facility and identified those FICA Casks which can be handled without any type of administrative (i.e., licensing or operating document) revisions or physical modifications.

The facility issessment then considered the potential cask-handling capability if the facility were to be changed. The first type of change assessed in this task considered possible changes that the utility might make to either the facility licensing documents or the administrative controls in order to remove one or more limiting conditions. Examples include the completion of a new cask-drop analysis and the relaxation of the requirement for a specified water depth over a fuel assembly during cask loading. Judgment was used in assessing potential changes, taking into account factors such as the crane design capacity, the age of the plant, the physical size of various areas of the plant, and obtaining any information on the cask that the facility was designed to handle.

Each facility assessment then addressed the possibility of removing plant restrictions by physically modifying the plant. The modifications considered in this case were those which appeared to be achievable without a major impact on the plant but which, when completed, would increase the cask handling capability of the facility. Examples of the physical modifications include the installation of an engineered plate to spread the weight of a cask over a larger specific floor area and modification to an anti-tipover device in the cask loading area. Major plant modifications, such as replacement of the cask-handling crane or moving of the building structural supports, were not considered.

Physical plant modifications are generally more difficult and costly to implement than changes to operating procedures or licensing documents. Specifically, many physical plant modifications require prior licensing document revisions; for this reason, these two types of changes are discussed separately. However, in some cases, the physical modifications assessed in this project may be more readily achievable than changes to licensing documents or administrative controls. The project did not include any of the detailed technical analyses

Facility Interface Capability Assessment (FICA) Summary Report 
that would be required for evaluation of the potential changes identified. Thus, the assessments are based only on judgment and engineering experience, and there is no certainty that the assessed changes can be achieved. To demonstrate achievability would have required technical analyses and the evaluation of licensing requirements that were beyond the scope of this project. 


\section{Technical Basis for the Project}

In order to assess the cask-handling capabilities at the facilities from which spent fuel will be accepted by the CRWMS, information was required on the physical dimensions of plant areas, crane weight limits, and floor load limits. Additional information, such as basic fuel characteristics data, have also been collected in order to put the assessments into context.

This section of the report disiusses:

1. data collected on fuel assembly dimensions,

2. specifications of the casks used as the basis of the cask-handling assessment, and

3. method of assessment used to determine facility capabilities.

\subsection{FUEL ASSEMBLY DIMENSIONS}

There are many different types of fuel assemblics with different physical dimensions and weights. Each reactor vendor has its own fuel handling system design, but differences do occur between successive generations of fuel anc fuel handling systems designed by the same vendor.

Although many parameters relating to geometry, weight, and radiological characteristics are also pertinent to loading SNF shipping casks, only cask handling at the relevant facilities was addressed. Two parameters relating to the SNF assembly are critical in assessing cask handling at the facility: overall fuel assembly length, and active fuel length.

The operating procedures or technical specifications for a facility will often specify the minimum depth of water required to be maintained over the top of an irradiated fuel assembly at all times in the spent-fuel pool. In some facilities, however, the minimum water depth is specified above the active portion of the fuel assembly and, thus, the active fuel length (i.e., the length in which the irradiated fuel is located) was required. In other facilities, the water cover requirement is specified indirectly by limiting the height to which a fuel assembly may be raised above the pool floor. Each of these limits necessarily restricts the length of cask into which fuel can be loaded at a facility, although this is not necessarily the most restrictive limit at the facility. 


\subsection{CASK PARAMETERS}

In order to assess the cask-handling capabilities for a given facility, the relevant parameters of casks that might be handled there were defined to be:

1. weight;

2. width across trunnions;

3. body diameter;

4. footprint diameter;

5. body length; and

6. length, including lifting yoke.

Figure 1 shows, generically, major cask features relating to in-facility handling and graphically depicts the geometric parameters used for determining the ability of a facility to handle the cask. From this set of parameters, the following key parameters were derived for assessing facility capability:

1. cask footprint area,

2. specific floor load,

3. width clearance for a square setdown area, and

4. width clearance for a circular setdown area.

During cask-handling operations, the weight of a cask varies according to the status of the cask, including, among other factors, whether the cask

1. is full of water or drained,

2. contains or does not contain SNF, and

3. is used with a redundant or a nonredundant yoke.

For each of the FICA Casks, the weight refers to the maximum weight required to be carried by the crane during cask-handling operations. 


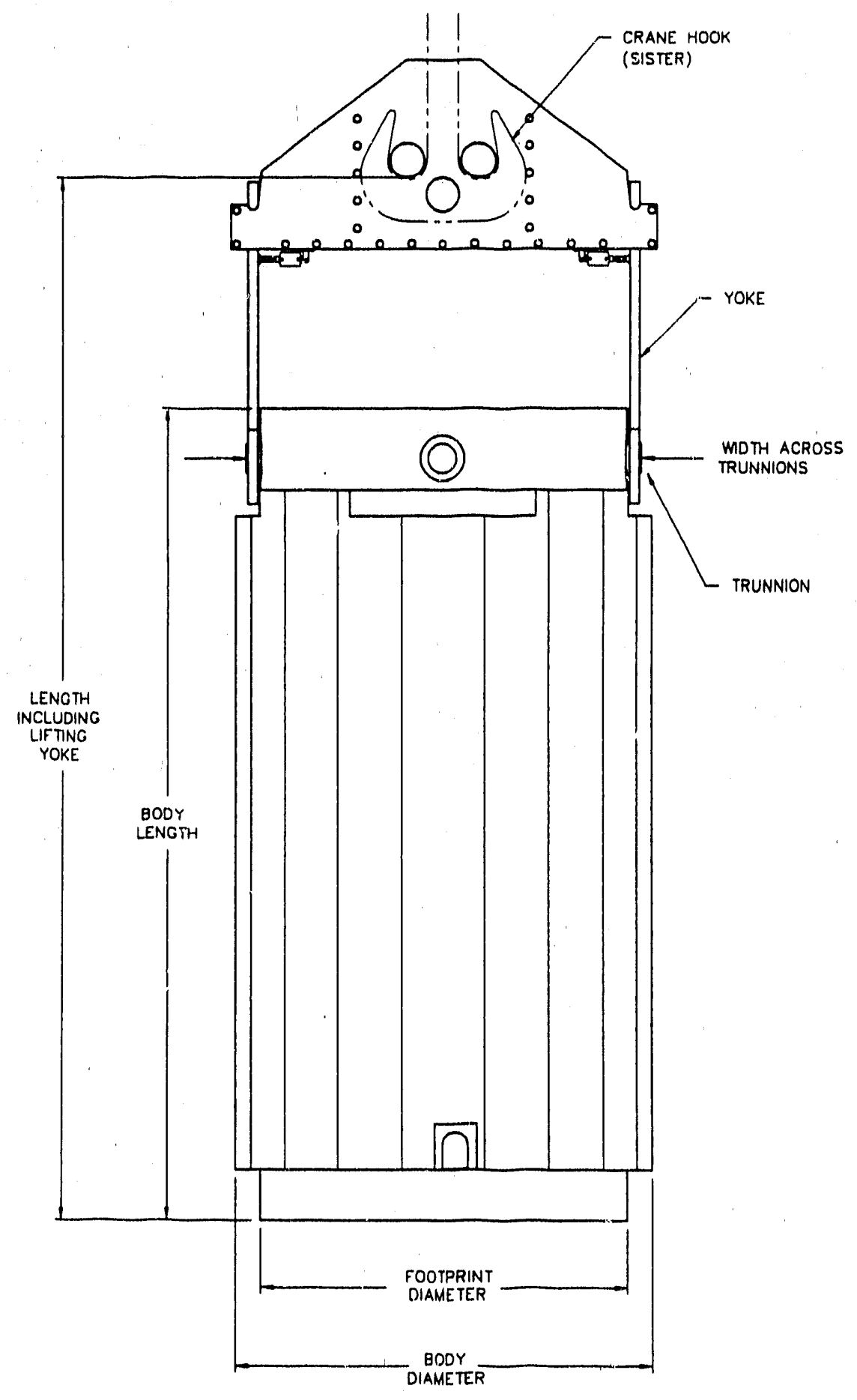

REF. FILE: SCS76005

Figure 1. Cask-handling dimension parameters. 
The preliminary designs of two LWT and two 100-ton R/B casks developed under OCRWM's Cask System Development Program (CSDP) were used to establish maximum cask bounding dimensions and weights for the FICA LWT cask and the FICA 100-ton R/B casks. The parameters selected for this case were representative of the CSDP casks, although they were not identical to any of the individual preliminary designs.

Since designs for OWT and 125-ton R/B casks have not been initiated by OCRWM, preliminary design dimensions were not available for these casks. Thus, representative dimensions for generic casks of these two sizes were derived, based on concepts developed in the early stages of the OCRWM cask development program and on existing commercial cask designs.

A set of dimension and weight parameters for LWT, OWT, 100-ton R/B, and 125-ton R/B program cask types was produced in May 1989 to be used as the basis for the facility cask-handling assessments. These parameters are shown in Table 2.

For the purpose of deriving floor loadings, a footprint diameter and area were modeled for each cask. The footprint, for the OWT cask only, was assumed to be a square; therefore, the dimension shown as the diameter for the OWT cask in Table 2 is not a true diameter and, for assessing cask handling clearances, only the body and trunnion dimensions were used.

In determining cask-handling capabilities, it is necessary to consider dimensional and weight limitations within the facility. For each facility, the cask parameters were compared with the facility layout and dimensions; in addition, the capability of the facility to handle each of the casks was defined.

\subsection{FACILITY PARAMETERS}

In order to assess facility cask-handling capabilities, the cask parameters established for the FICA Casks were compared with the dimensions and weight limitations of all relevant plant features at each iacility.

In each facility, the cask travel path was considered as four separate elements:

1. receiving area (also called the vehicle bay),

2. upending area (in most plants, the same as the receiving area),

3. decontamination area, and

Facility Interface Capability Assessment (FICA) Summary Report 
Table 2. FICA Cask parameters

\begin{tabular}{|c|c|c|c|c|}
\hline \multirow{2}{*}{ Parameter } & \multicolumn{3}{|c|}{ Type of cask } & \multirow[b]{2}{*}{ 125-ton $\mathrm{R} / \mathrm{B}$} \\
\hline & LWT & OWT & $100 \cdot \operatorname{ton} R / B$ & \\
\hline \multicolumn{5}{|l|}{ Dimensions" } \\
\hline $\begin{array}{l}\text { Weight, } \\
\text { tons }(W)\end{array}$ & 28 & 40 & 100 & 125 \\
\hline $\begin{array}{l}\text { Width across trunnions, } \\
t_{1} \text { in. }(T)\end{array}$ & 4,5 & 5,6 & 7. 10 & 8,5 \\
\hline $\begin{array}{l}\text { Body diameter, } \\
t, \text { in. }(B)\end{array}$ & 3,6 & 4,8 & 7,4 & 8 \\
\hline $\begin{array}{l}\text { Footprint dlameter } \\
H_{1} \text { in. }(F)\end{array}$ & 2,5 & 5,6 & 6,5 & 6, 11 \\
\hline $\begin{array}{l}\text { Body Length, } t_{1} \\
\text { in. }\end{array}$ & 17,0 & 17,2 & 17,2 & 17,2 \\
\hline $\begin{array}{l}\text { Length including litting } \\
\text { yoke, } t, \text { in. }\end{array}$ & 22,6 & 23,1 & 22, & 22. \\
\hline Derived Parameters & & & & \\
\hline $\begin{array}{l}\text { Footprint area, } \\
\mathbb{t}^{2}(A)\end{array}$ & 4.5 & 19.6 & 32.3 & 37.5 \\
\hline $\begin{array}{l}\text { Specific floor load, } \\
\text { lbs/t/t } \\
{[(2000 \cdot W) / A]}\end{array}$ & 13,000 & 4,100 & 6,200 & 6,700 \\
\hline $\begin{array}{l}\text { Width clearance - } \\
\text { square setdown area } \\
(B+2 \text { in.) } \\
t, \text { in. }\end{array}$ & 3,8 & 4,10 & 7,6 & 8,5 \\
\hline $\begin{array}{l}\text { Width clearance - } \\
\text { circular setdown } \\
\text { area }(T+10 \text { in.) } \\
t, \text { in. }\end{array}$ & 5,3 & 6,4 & 8,8 & 9,3 \\
\hline
\end{tabular}

"Letters in parentheses are abbreviations for the parameters and derived parameters. Formulas give values for derlved parameters. 


\section{4. fuel loading area.}

Figures 2-5 show simplified, generic schematic elevation and plan views of typical plant layouts for PWR and BWR cask-handling facilities. Plant clearance limitations were considered throughout all stages of the cask handling and loading operations until the cask was mounted back on a vehicle in the receiving area. In addition, the crane weight capacity, operational clearances, and floor load limitations along the cask travel path were taken into account.

As discussed in Sect. 3.1, there is a requirement in each facility to maintain a specified minimum water cover over a fuel assembly during cask loading. This ensures that sufficient shielding is maintained to meet radiation control requirements. Although specified in a number of ways, this water cover requirement was also considered in determining cask-handling capability.

\subsection{OPERATING CONTROLS}

in assessing plant limitations relative to cask handling, there are a number of operating controls that are specified in the plant Technical Specifications, Operating Procedures, and Final Safety Analysis Report (FSAR). In many cases, these are controlled by mechanical interlocks or limit switches on equipment; in some cases, however, they are controlled administratively.

One control that is, in some cases, the most restrictive relative to cask handling is the imp ssed calculated floor load limits. Prior to handling any cask at a facility, it is necessary to iemonstrate that each area where the cask may be set down can accept the weight, and weight distribution, of the cask. In cases where these data were not available, assumptions were made to allow facility assessments to be completed.

Finally, the design capacity of the cane for each facility was also identified and, in cases where the crane capacity had been downrated from its design value by imposition of an operating limit lower than the design capacity, this operating limit was also identified. In some instances, the downrating was introduced to provide an additional load margin for all heavy-load operations, while in others it followed completion of a cask drop analysis and applied only to cask-handling operations. Where such operating controls were imposed, these were taken into account in completing the cask handling assessments.

Facility Interface Capability Assessment (FICA) Summary Report 


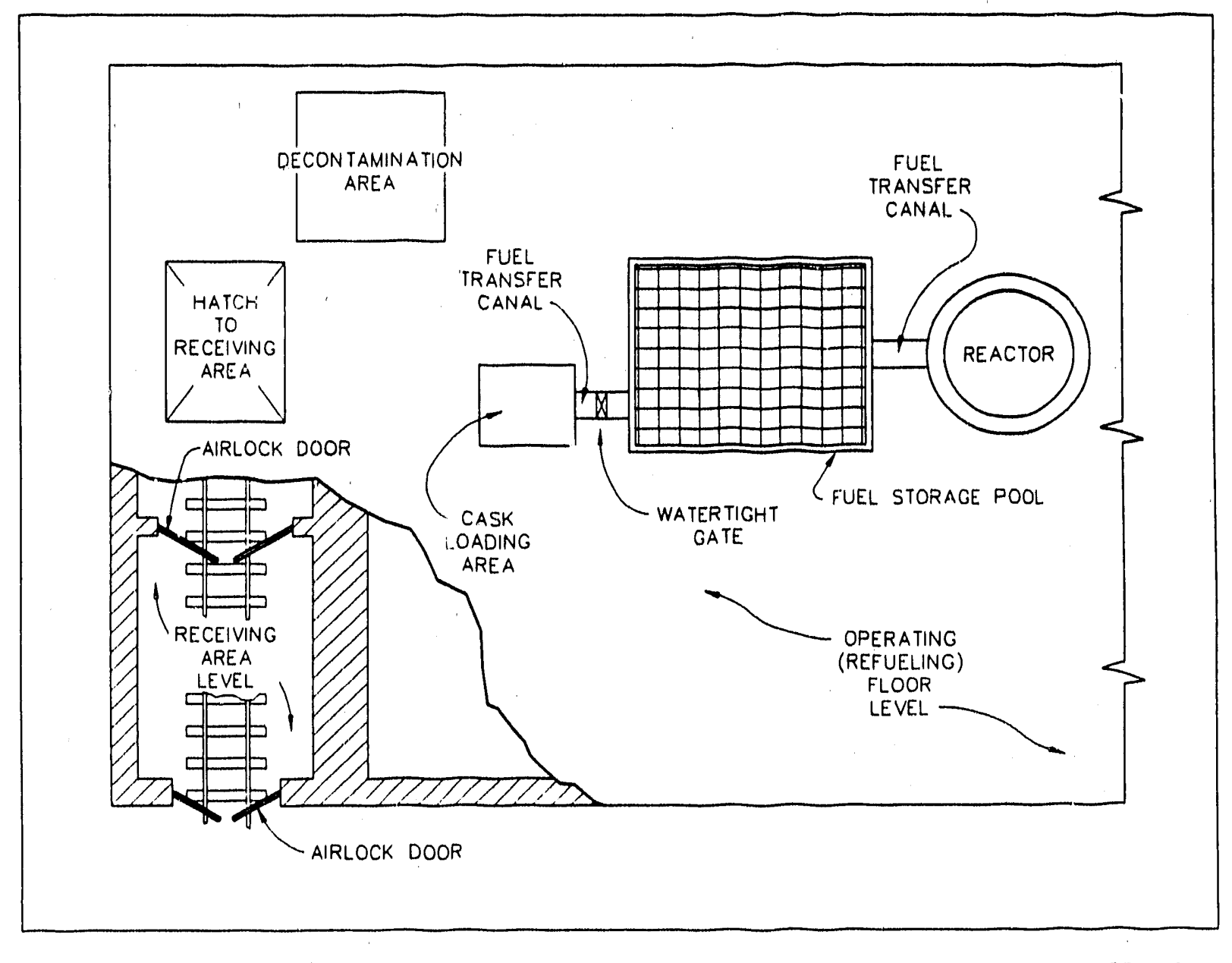

SG376001

Figure 2. Section view of generic PWR cask-handling facility.

Facility Interface Capability Assessment (FICA) Summary Report 


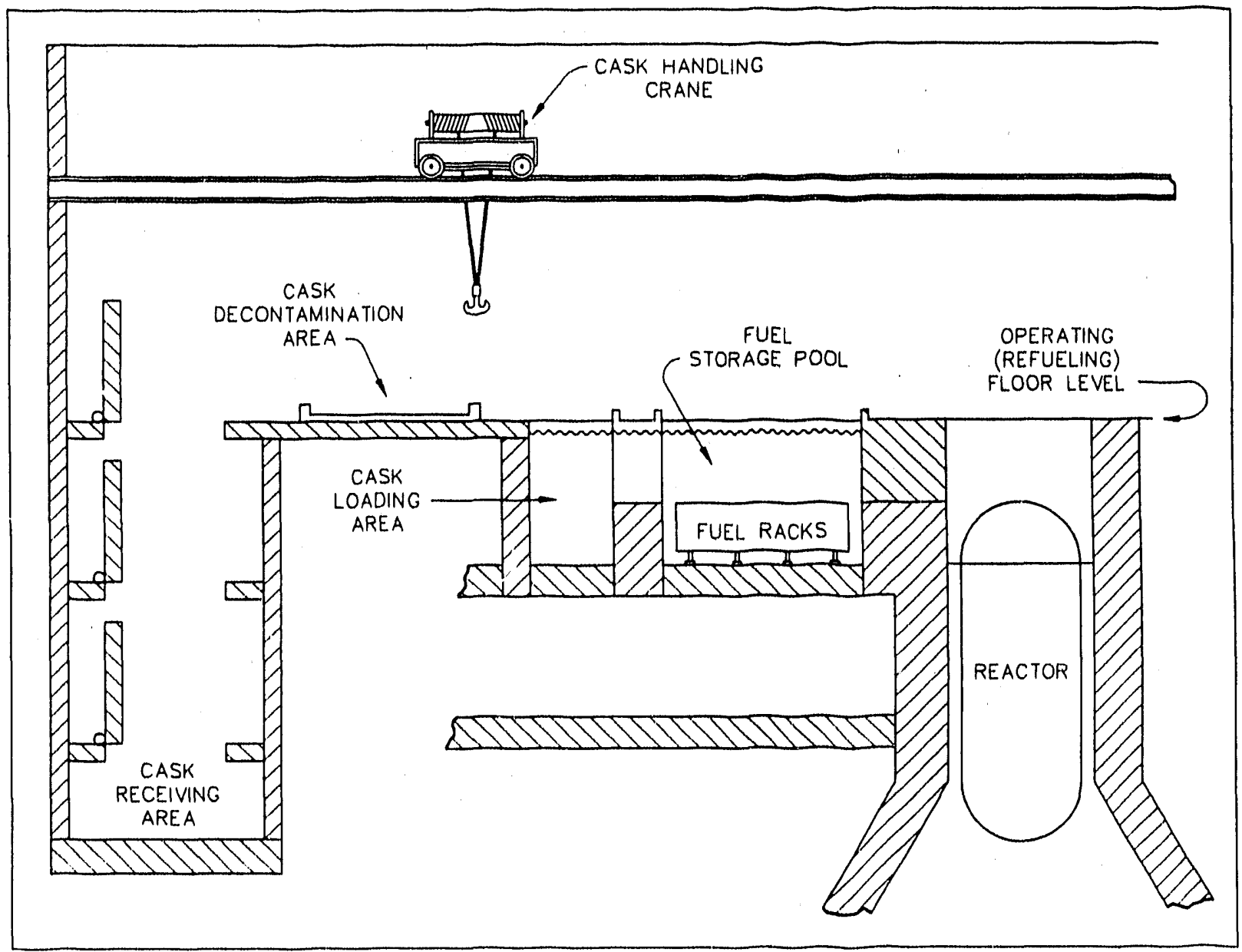

50,376002

Figure 3. Plan view of generic PWR cask-handling facility.

Facility Interface Capability Assessment (FICA) Summary Report 


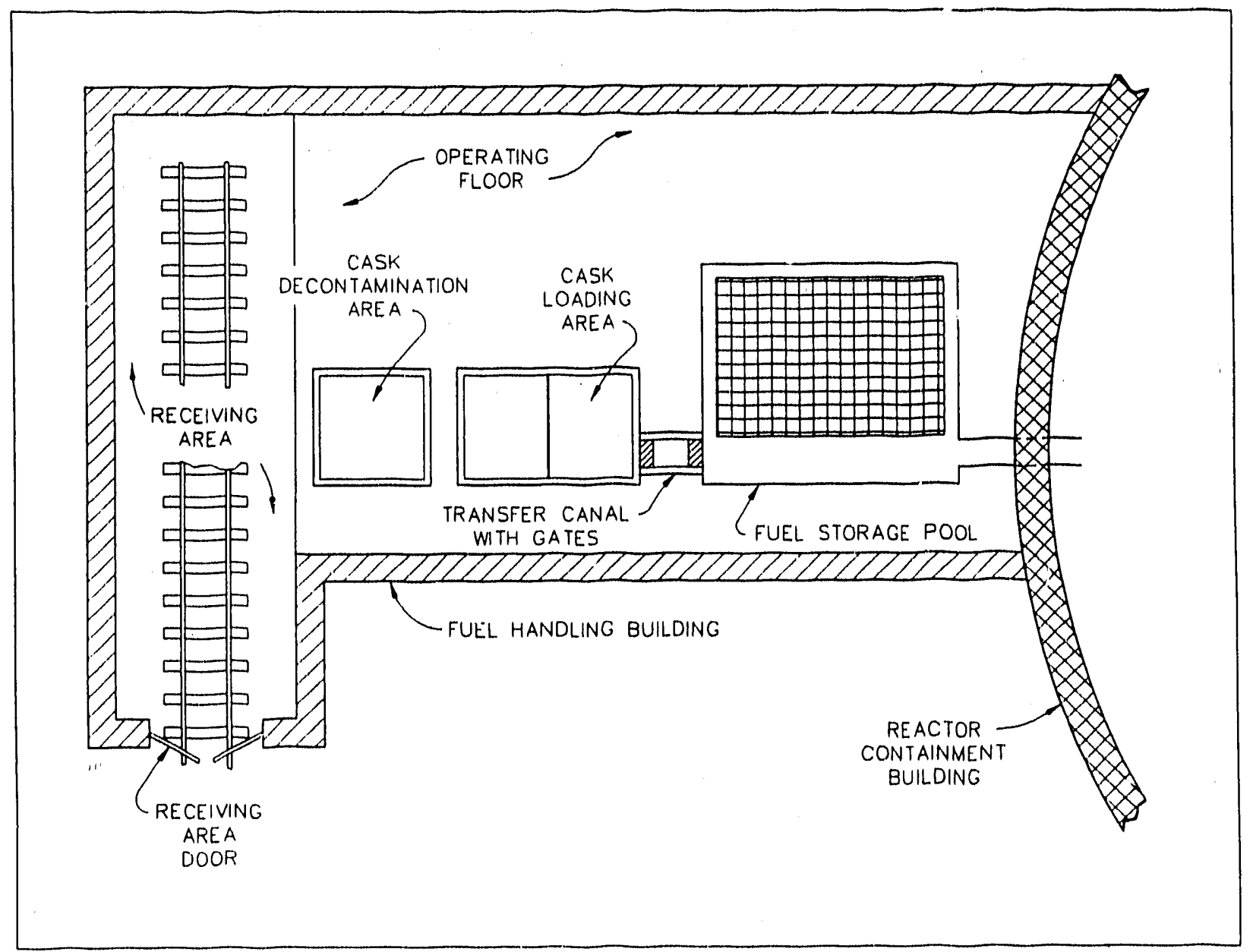

50376003

Figure 4. Section view of generic BWR cask-handling facility.

Facility Interface Capability Assessment (FICA) Summary Report 


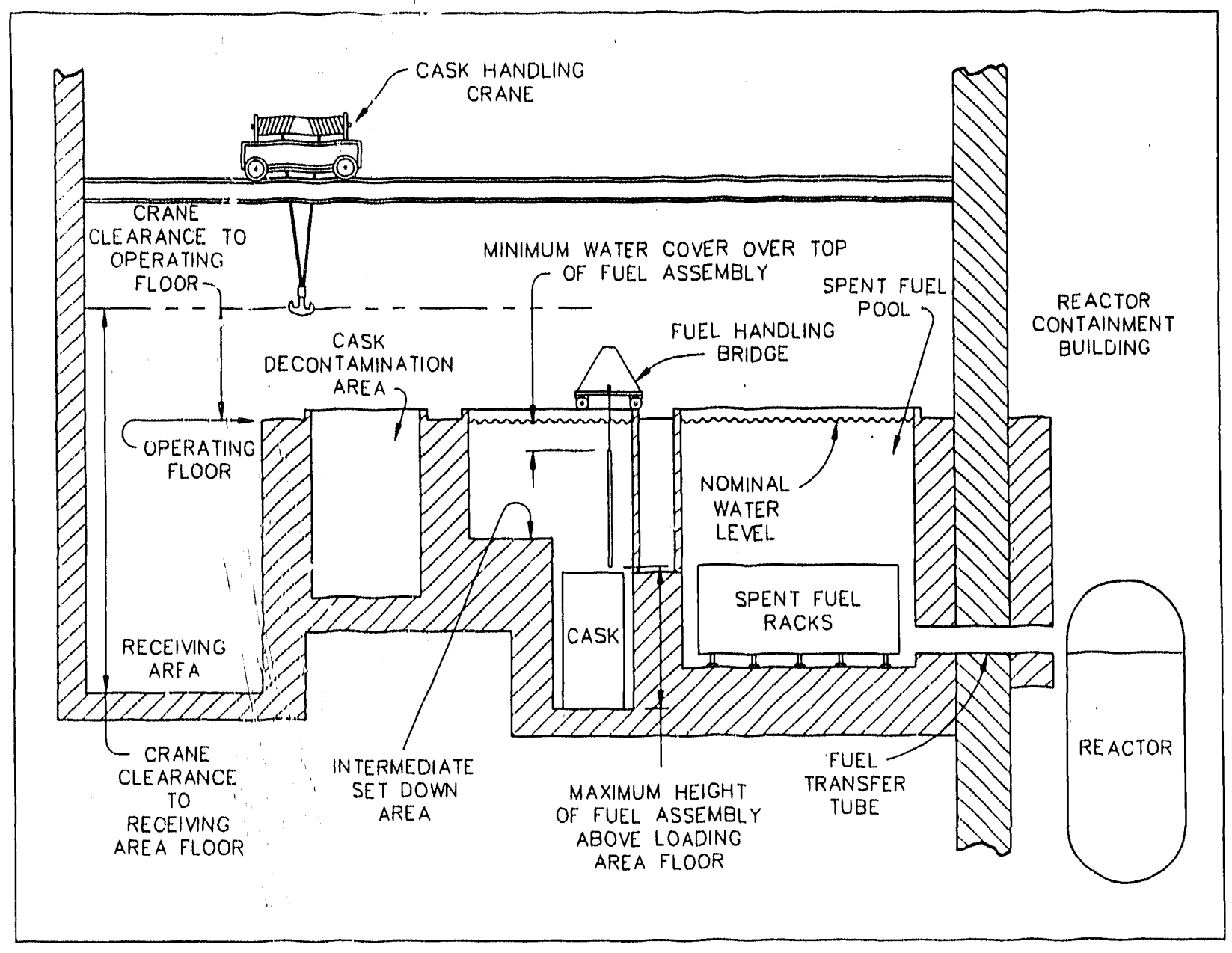

$\operatorname{sic} 376004$

Figure 5. Plan view of generic BWR cask-handling facility.

Facility Interface Capability Assessment (FICA) Summary Report 


\section{FICA Project Results}

This section summarizes the results of the cask handling assessments for each of the 122 facilities assessed in the FICA project. The detailed data, which form the basis for these assessments, are documented separately in the FICA Project Report.

As discussed in Sect. 3, the assessment of cask-handling capability for each facility was based on information provided by the ":ility or plant operator in engineering documents and additional information obtained during the site visits. The main focus of the data collection activity and the site visits was centered on the identification of plant limitations restricting the current cask-handling capability and consideration of how these restrictions could be removed. For each facility, the limiting values for each critical cask parameter (length, diameter, and weight) were determined. The assessment was then performed by comparing these limiting values with the dimensions of the FICA Casks (as defined in Table 2). This resulted in identification, for each facility, of the largest of the FICA Casks that could currently be handled. The results of this part of the assessment are presented in Sect. 4.1.

After the current cask-handling capability for each facility had been established, the possibility of increasing that capability by administrative changes (i.e., by revising licensing or administrative controls) and/or by making limited physical plant modifications was considered. The potential cask-handling capabilities, if these changes were implemented, are presented and compared with current cask-handling capabilities in Sect. 4.2.

\subsection{CURRENT CASK-HANDLING LIMITS}

The three major parameters relevant to the assessment of cask-handling capabilities for the facilities are:

1. the maximum length cask which can be handled in the plant,

2. the maximum diameter cask which can be handled in the plant, and

3. the maximum weight cask which can be handled in the plant.

These parameters, when compared with the FICA Cask parameters, were used to determine the current facility cask-handling capabilities. Each of these parameters is considered separately in the succeeding sections.

Facility Interface Capability Assessment (FICA) Summary Report 


\subsubsection{Cask Diameter Limits}

One dimensional constraint considered was the cask diameter. Table 3 summarizes the number of facilities which can, and the number which cannot, currently accommodate each of the FICA Casks, considering the cask diameter as a facility operating constraint. The results show that, from a diameter standpoint, 84 of the 122 facilities (69\%) can currently accommodate all FICA Casks, whereas 120 of the 122 facilities (98\%) can accommodate the FICA LWT cask.

Table 3. Effect of cask body diameter limitations on assessed cask-handling capability

\begin{tabular}{cccc}
\hline Cask body diameter & $\begin{array}{c}\text { Cask type of this } \\
\text { body diameter }\end{array}$ & $\begin{array}{c}\text { Can currently } \\
\text { handle cask body } \\
\text { diameter } \\
\text { (No. of facilities) }\end{array}$ & $\begin{array}{c}\text { Cannot currently } \\
\text { handle cask body } \\
\text { diameter } \\
\text { (No. of facilities) }\end{array}$ \\
\hline $3 \mathrm{ft} 6$ in. & LWT & 120 & 2 \\
$4 \mathrm{ft} 8$ in. & OWT & 118 & 4 \\
$7 \mathrm{ft} 4$ in. & 100 -ton & 96 & 26 \\
$8 \mathrm{ft} 3$ in. & 125 -ton & 84 & 38 \\
\hline
\end{tabular}

\subsubsection{Cask-Handling Capability Based on Cask Length}

The second dimensional constraint considered was cask length. The length limitation was considered in the project in two ways: (1) constraints arising from the "slung" length when the cask-yoke combination is suspended from the cask-handling crane hook, and (2) constraints arising from the cask body length. As will be described in Sect. 4.2, where the slung length was found to be the limiting parameter, the constraint resulted from a general headroom limitation within the facility or an obstruction over which the cask must be lifted at some point on the cask travel path. In all but one case involving a general headroom restriction, the use of a shorter yoke would allow the FICA Casks to be handled. Thus, the cask body length was used as the length discriminator in the assessment.

At almost all of the facilities where the cask body length is a limiting parameter, the constraining factor was found to be the requirement for a specified minimum depth of water to be maintained over a fuel assembly during cask loading operations. Table 4 summarizes the number of facilities that can, and the number that cannot, currently accommodate each

Facility Interface Capability Assessment (FICA) Summary Report 
of the FICA Casks, considering the cask body length as a facility operating constraint. The results show that 83 of the 122 facilities (68\%) can currently accommodate, from a cask body length standpoint, any of the FICA Casks. By reducing the cask body length by 2 in. (i.e., considering only the FICA LWT cask), the number of facilities that can accommodate this cask increases slightly from $83(68 \%)$ to $88(72 \%)$ of the 122 facilities.

Table 4. Effect. of cask length limitations on assessed cask-handling capability

\begin{tabular}{lllc}
\hline $\begin{array}{c}\text { Cask body } \\
\text { length }\end{array}$ & $\begin{array}{c}\text { Cask type of this body } \\
\text { length }\end{array}$ & $\begin{array}{l}\text { Can currently } \\
\text { handle cask } \\
\text { body length } \\
\text { (No. of facilities) }\end{array}$ & $\begin{array}{c}\text { Cannot currently } \\
\text { handle cask } \\
\text { body length } \\
\text { (No. of facilities) }\end{array}$ \\
\hline $17 \mathrm{ft} 0$ in. & LWT & 88 & 34 \\
$17 \mathrm{ft} 2$ in. & $\begin{array}{l}\text { OWT, } \\
100-\text {-ton, } \\
125 \text {-ton }\end{array}$ & 83 & 39 \\
\hline
\end{tabular}

Thus, in comparing ihe results for both cask diameter (Sect. 4.1.1) and cask length (Sect. 4.1.2), it is apparent that diameter is a much greater discriminator in determining the ability of a facility to handle casks.

\subsubsection{Cask Weight Limits}

Two primary factors were used to determine the cask weight limitations at the facilities assessed: crane capacity, and floor load limitations.

Although these are independent parameters, the design capacity of the crane is downrated in some facilities to a lower operating capacity to reflect floor load limitation. In others, a floor load limitation is imposed directly as a technical specification without downrating the crane.

Table 5 summarizes the number of facilities that can, and the number that cannot, currently accommodate each of the FICA Casks, when the cask weight is considered as a facility operating constraint. The results show that, from a weight standpoint, only 32 of the 122 facilities (26\%) can currently accommodate all FICA Casks, whereas 100 of the 122 facilities $(82 \%)$ can accommodate the FICA LWT Cask.

Facility Interface Capability Assessment (FICA) Summary Report 
Table 5. Effect of cask weight limitations on assessed cask-handling capability

\begin{tabular}{cccc}
\hline $\begin{array}{c}\text { Cask weight } \\
\text { (tons) }\end{array}$ & $\begin{array}{c}\text { Cask type of this } \\
\text { weight }\end{array}$ & $\begin{array}{c}\text { Can currently } \\
\text { handle cask weight } \\
\text { (No. of facilities) }\end{array}$ & $\begin{array}{c}\text { Cannot currently } \\
\text { handle cask weight } \\
\text { (No. of facilities) }\end{array}$ \\
\hline 28 & LWT & 100 & 22 \\
40 & OWT & 97 & 25 \\
100 & 100 -ton & 74 & 48 \\
125 & 125 -ton & 32 & 90 \\
\hline
\end{tabular}

\subsubsection{Current Capability Using Combined Limits}

The preceding section considered each of the limits or constraints separately; however, all three must be considered concurrently to completely define the current capability of a facility.

When the length, diameter and weight are considered simultaneously, the current facility capability is as summarized in Table 6. This table summarizes the number of facilities that can, and the number that cannot, presently accommodate each of the FICA Casks, when the three limiting parameters are combined as a facility operating constraint. The results show that only 26 of the 122 facilities (21\%) can currently accommodate all FICA Casks. Only 73 of the 122 facilities $(60 \%)$ can accommodate the smallest of those casks considered, i.e., the FICA LWT cask. The potential for improving the ability of accommodating these casks at the facilities is addressed in the next section.

\subsection{POTENTIAL FOR IMPROVED CASK HANDLING CAPABILITIES}

This section summarizes the results of assessing the potential for increasing the cask-handling capability for each of the 122 facilities in the event that actions should be taken to (1) revise administrative and licensing controls, and/or (2) physically modify the facility. As with the assessment for current capability, the three parameters -- length, diameter, $a_{2}$ - - weight of the FICA Casks -- were used in assessing the potential for improved handling capabilities. No internal dimensions or other design parameters were specified for these casks. Consequently, no assessment was made of the suitability of the casks for shipping particular types of fuel. Also, although the project data base includes some information on cask transportation experience, no assessment was made of how this experience might contribute to enhanced capability or how casks could be shipped from the facility sites.

Facility Interface Capability Assessment (FICA) Summary Report 
Table 6. Effects of combined cask length, diameter, and weight limitations on assessed cas.'-handling capability

\begin{tabular}{|c|c|c|c|}
\hline Type of cask & $\begin{array}{l}\text { Cask parameters: } \\
\text { length; } \\
\text { diameter; and } \\
\text { weight }\end{array}$ & $\begin{array}{c}\text { Can currently } \\
\text { handle cask weight } \\
\text { (No. of facilities) }\end{array}$ & $\begin{array}{l}\text { Cannot currently } \\
\text { handle cask weight } \\
\text { (No. of facilities) }\end{array}$ \\
\hline \multirow[t]{3}{*}{ LWT } & $17 \mathrm{ft}$ & 73 & 49 \\
\hline & $3 \mathrm{ft}, 6 \mathrm{in}$.; & & \\
\hline & 28 tons & & \\
\hline \multirow[t]{3}{*}{ OWT } & $17 \mathrm{ft}, 2$ in.; & 68 & 54 \\
\hline & $4 \mathrm{ft}, 8$ in.; & & \\
\hline & 40 tons & & \\
\hline \multirow[t]{3}{*}{ 100-ton $\mathrm{R} / \mathrm{B}$} & $17 \mathrm{ft}, 2$ in.; & 50 & 72 \\
\hline & $7 \mathrm{ft}, 4$ in.; & & \\
\hline & 100 tons & & \\
\hline \multirow[t]{3}{*}{125 -ton $\mathrm{R} / \mathrm{B}$} & $17 \mathrm{ft}, 2$ in.; & 26 & 96 \\
\hline & $8 \mathrm{ft}, 3$ in.; & & \\
\hline & 125 tons & & \\
\hline
\end{tabular}


It is not intended here to either recommend whether any of the administrative changes, licensing changes, or physical modifications considered should be completed or to imply that the utility or plant operator for any facility has expressed the intention of completing any facility changes.

Figure 6 presents, in summary form, the results of the assessment to determine the potential for improved cask-handling capabilities. The number of facilities that can currently handle each of the FICA Casks (see Table 6) is shown in the front row of Fig. 6. The center row shows the estimated number of facilities that were assessed as being able to handle each of the FICA Casks if administrative/licensing changes were made, while the back row presents the number of facilities that were assessed as being able to handle each of the casks if the physical modifications considered in this assessment were implemented at the facility and/or the administrative/licensing changes were implemented.

The assessment showed that only the LaCrosse plant would be incapable of handlir $g$ the FICA LWT cask if all the changes considered within the FICA project were implemented. The handling of casks at LaCrosse is hampered by limited space in the cask upending area, and special actions in terms of site-specific equipment and procedures would be required to accommodate even the FICA LWT Cask. The assessment also showed that two other plants, Ginna and Yankee Rowe, would be unable to handle the FICA OWT casks if all the changes within the scope of the project were implemented.

More-detailed results from the analysis of the improved cask handling capabilities are presented in the following sections, which address the potential for improved facility cask handling capability for each of the FICA Casks.

\subsubsection{Potential for Improved LWT Cask-Handling Capability}

The results of the assessment for improving facility capability to handle the FICA LWT Cask are summarized in Fig. 7. The histogram presents the number of facilities estimated to be capable of handling the LWT Cask (shaded bars), as well as the number estimated to be incapable of handling the LWT Cask (solid bars) for three scenarios:

1. current capability,

2. if administrative/licensing changes only were implemented, and

3. if physical modification to the facility and/or administrative/licensing changes were implemented.

Of the 122 facilities assessed in the FICA project, 73 are estimated to be able to currently handle the LWT Cask.

Facility Interface Capability Assessment (FICA) Summary Report

24 


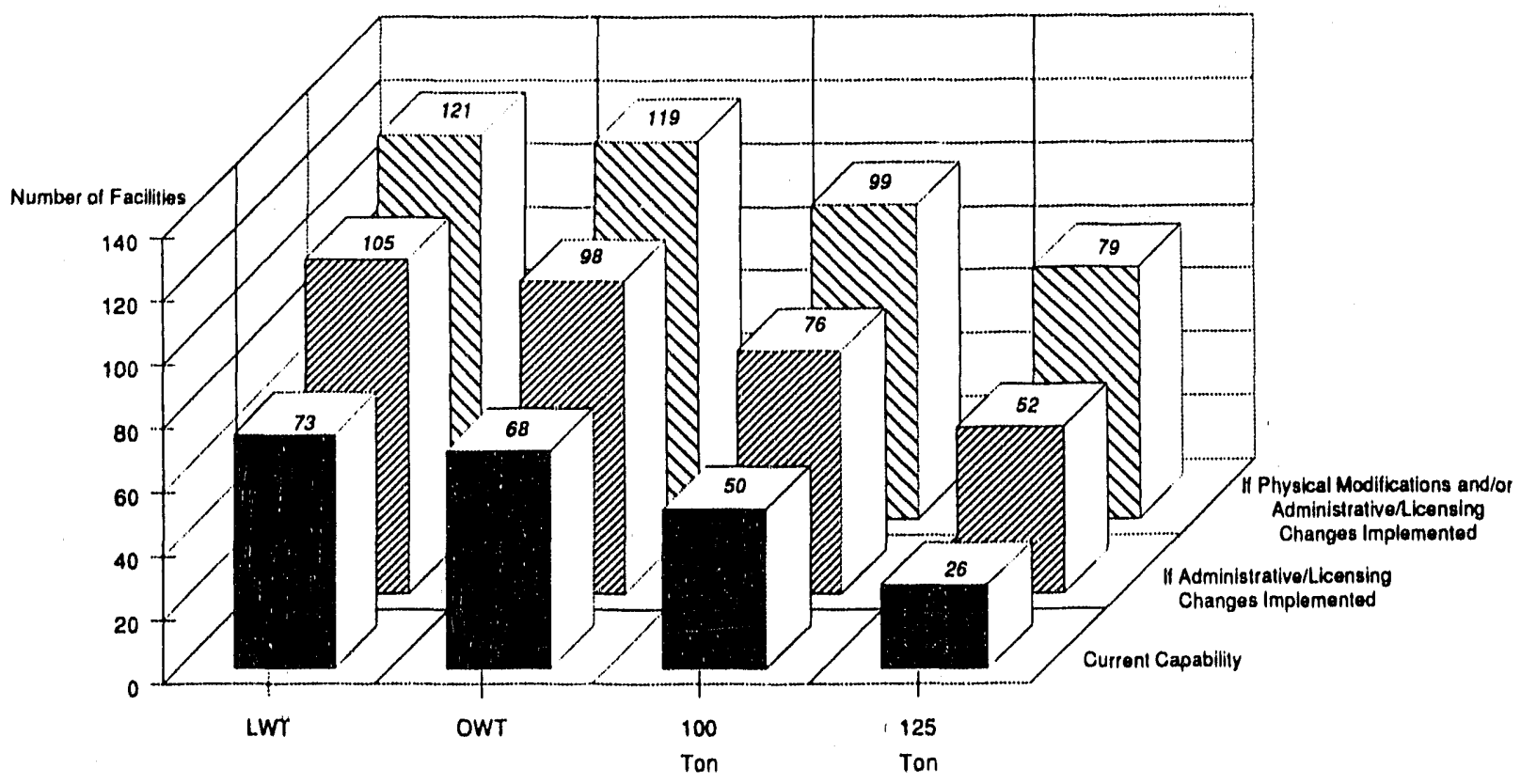

Figure 6. Summary results of current and potential improved cask-handling capabilities.

Facility Interface Capability Assessment (FICA) Summary Report 


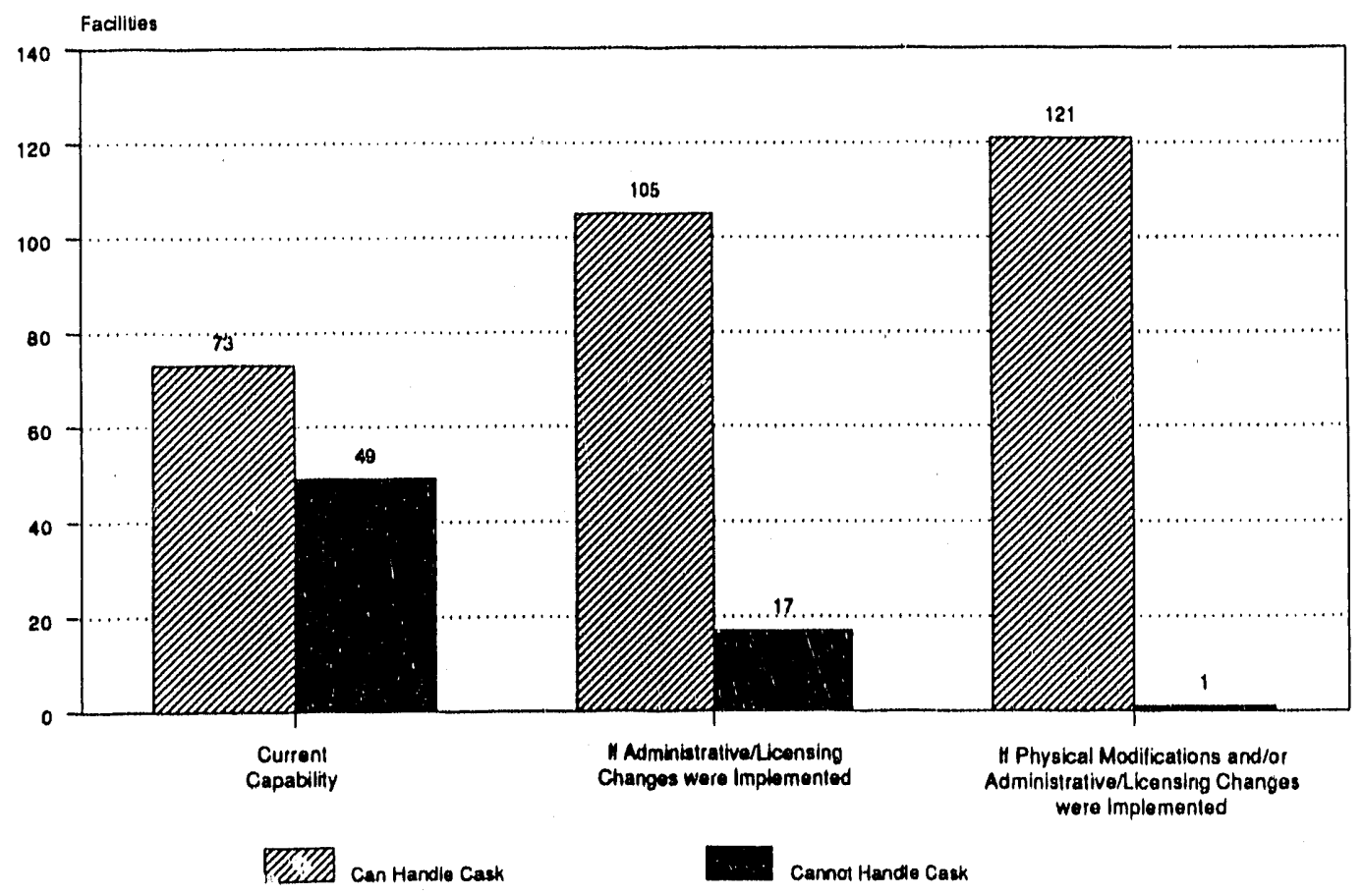

Figure 7. Projected FICA LWT cask-handling capability. 
Nearly two-thirds of the facilities not currently capable of handling the LWT cask could potentially remove that constraint by implementing administrative/licensing changes; such actions would increase the capability from 73 to 105 . The administrative/licensing changes considered here range, in complexity, from analyses to support a reduction in the specified water cover over a fuel assembly during cask loading operations to detailed analyses required to allow removal of crane capacity or floor loading limitations.

In addition, if the facility modifications addressed were implemented, it is estimated that only one facility could not then subsequently handle the FICA LWT Cask. The modifications that were considered were those which appeared to be achievable without a major impact on the plant but which, when completed, would increase the cask-handling capability of the facility. Examples of the physical modifications include the installation of an engineered plate to spread the weight of a cask over a larger specific floor area and modification to an anti-tipover device in the cask loading area. Major plant modifications, such as replacement of the cask-handling crane or moving building structural supports, were not considered.

The facility that was assessed as not being able to handle the LWT cask, even if the assessed upgrades were implemented, is LaCrosse. The most restrictive segment of the in-plant cask travel path at LaCrosse is in the cask upending area. As the cask enters the upending area from the airlock, with its axis horizontal, the layout of the plant requires that the upending operation start before the cask is fully out of the airlock. Handling experience with existing casks confirms that none of the FICA Casks could be handled without considerable effort beyond those evaluated in this study. It is projected that special equipment would be required to facilitate handling of the casks. At the minimum, a horizontal lifting fixture and a rotating cradle on the cask transfer cart would be required. In addition, it is possible that a special lifting yoke would be required to facilitate underwater operations at LaCrosse. In order to accommodate the FICA LWT Cask, modifications to operating procedures for the uprighting of the cask, as discussed above, would be necessary. Removal of the airlock could be considered as an alternative since the plant is permanently shut down. This may be possible but was not considered to be within the definition of facility modification for the purposes of this project.

\subsubsection{Potential for Improved OWT Cask-Handling Capability}

The results of the assessment for improving facility capability to handle the FICA OWT Cask are summarized in Fig. 8.

Of the 122 facilities assessed in the FICA project, 68 are estimated to be currently capable of handling the OWT Cask.

Facility Interface Capability Assessment (FICA) Summary Report 


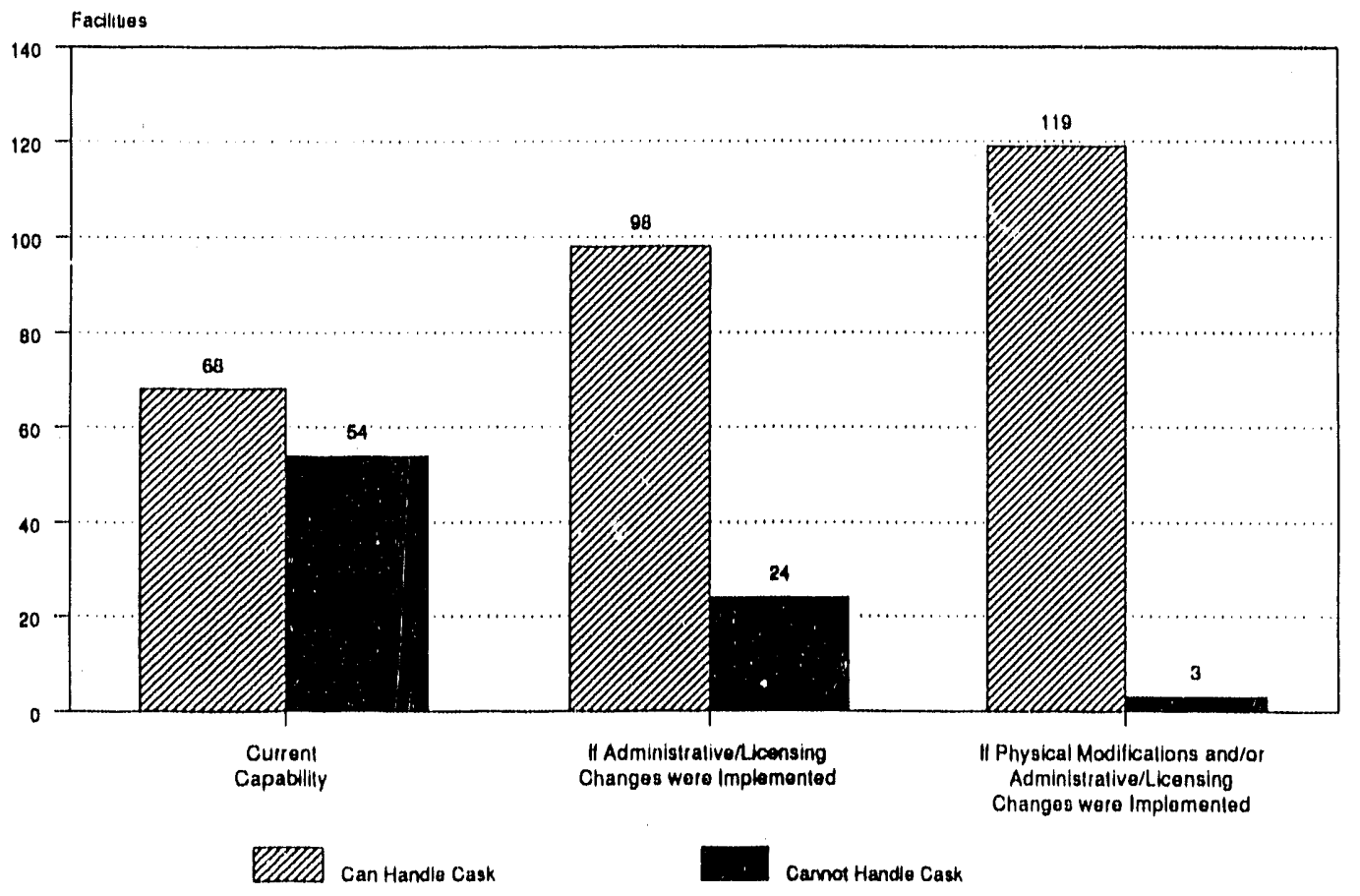

Figure 8. Projected FICA OWT cask-handling capability. 
More than half of the facilities not currently capable of handling the OWT cask may be able to remove that constraint by implementing administrative/licensing changes, which would increase the number of capable facilities from 68 to 98.

In addition, if the facility modifications addressed here were implemented, it is estimated that only three facilities could not then handle the FICA OWT Cask.

The facilities that were assessed as being incapable of handling the OWT cask, even if the assessed upgrades could be implemented, are LaCrosse, Ginna, and Yankee Rowe. The cask-handling limitations at LaCrosse were described in Sect. 4.2.1. In the case of the Ginna plant, the operating capacity of the cask handling crane could not be increased above 30 tons without major modifications, thereby limiting the facility to use of the LWT Cask. In the case of the Yankee Rowe plant, the dimensions of the cask loading area and the door to the fuel building preclude the use of the FICA OWT Cask.

\subsubsection{Potential for Improved 100-ton R/B Cask-Handling Capability}

The results of the assessment for improving facility capability to handle the FICA 100-ton R/B Cask are summarized in Fig. 9.

Of the 122 facilities assessed in the FICA project, 50 are currently estimated to be able to handle the 100-ton R/B Cask.

Approximately one-third of the facilities not currently capable of handling the 100-ton R/B cask could potentially remove that constraint by implementing administrative/licensing changes. This action would increase the number of facilities capable of handling the 100-ton $\mathrm{R} / \mathrm{B}$ cask from 50 to 76 .

In addition, if the facility modifications addressed here were implemented, it is estimated that the number of facilities capable of handling the FICA 100-ton R/B Cask could be increased from 76 to 99 . Thus, approximately $19 \%$ of the facilities were assessed as being incapable of handling the 100-ton R/B cask even if the assessed modifications were to be implemented.

\subsubsection{Potential for Improved 125-ton R/B Cask-Handling Capability}

The results of the assessment for improving facility capability to handle the FICA 125-ton R/B Cask are summarized in Fig. 10.

Of the 122 facilities assessed in the FICA project, 26 are currently estimated to be able to handle the 125.ton R/B Cask, which is approximately a factor of 2 reduction of the estimated current capability for handling the 100 -ton cask.

Facility Interface Capability Assessment (FICA) Summary Report 


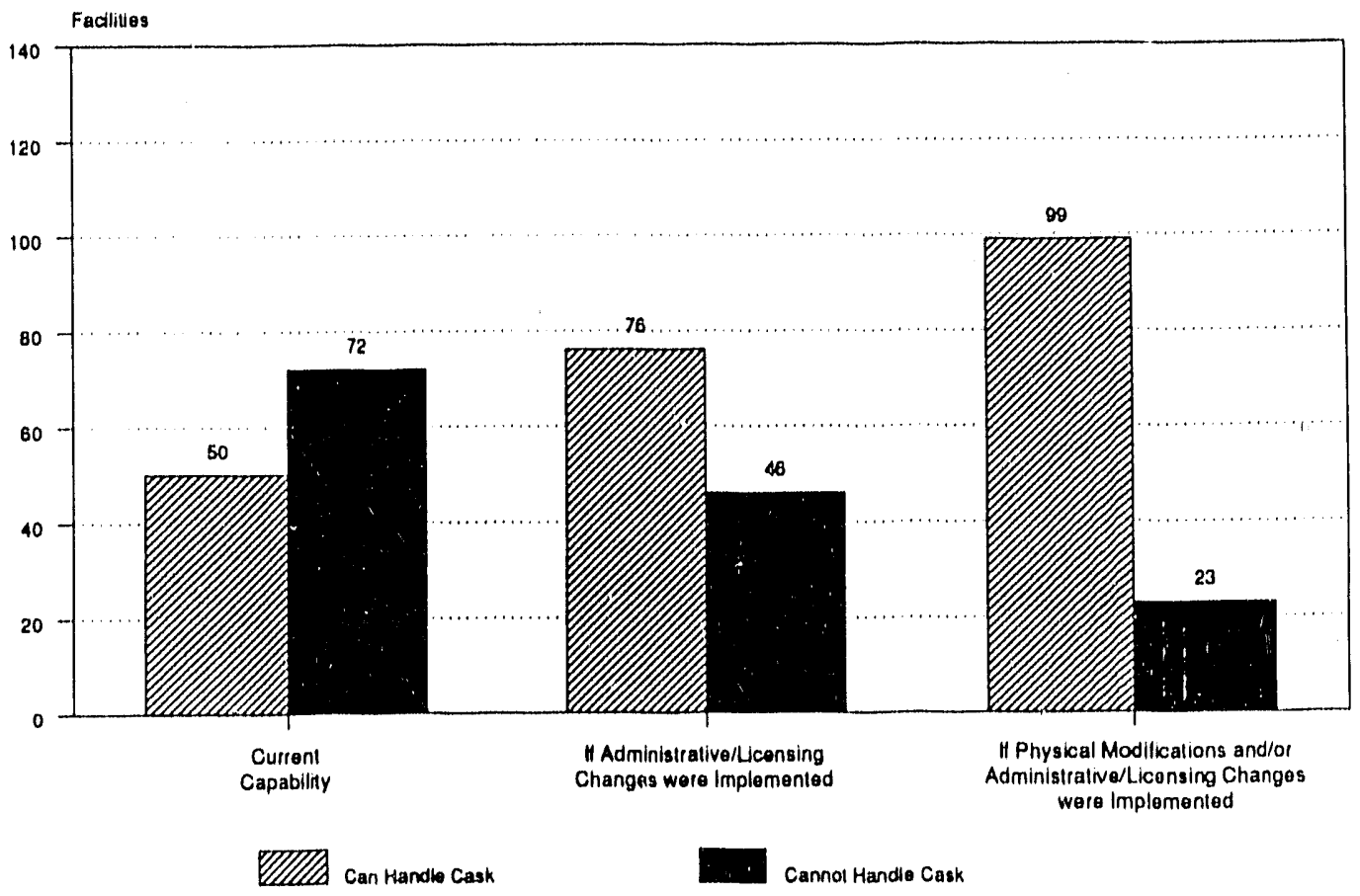

Figure 9. Projected FICA 100-Ton R/B cask-handling capability. 


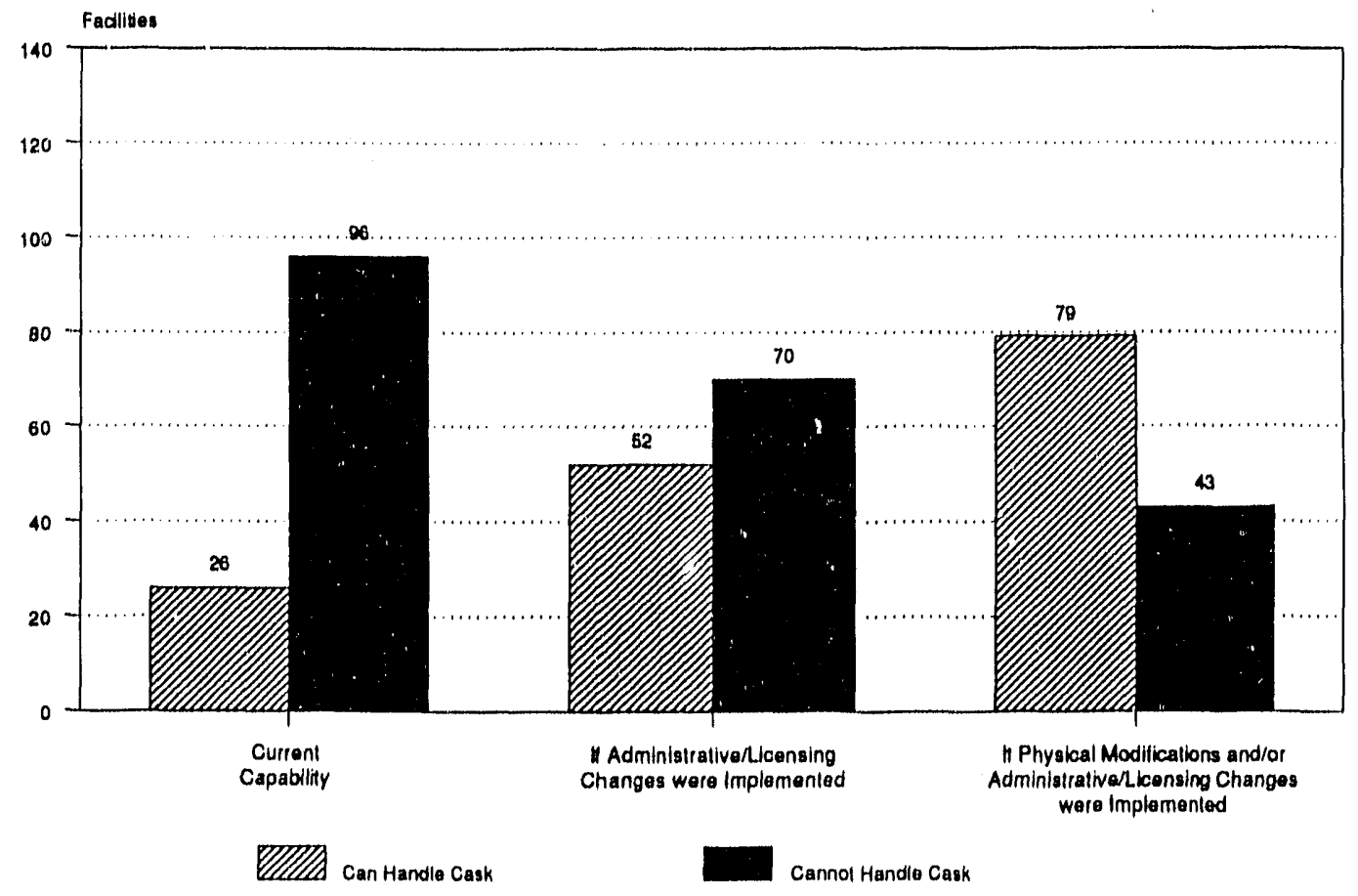

Figure 10. Projected FICA 125-Ton R/B cask-handling capability.

Facility Interface Capability Assessment (FICA) Summary Report. 
Approximately one-third of the facilities currently incapable of hitating the 125 -ton $\mathrm{R} / \mathrm{B}$ cask could potentially remove that constraint by implementing administrative/licensing changes; this would increase the number of facilities capable of handling the 125-ton R/B cask from 26 to 52 . Thus, even with the administrative/licensing changes, more than half the facilities would be incapable of handling this cask.

In addition, if the facility modifications addressed here were implemented, it is estimated that the number of facilities capable of handling the FICA 125-ton R/B Cask could be increased from 52 to 79 . Thus, the assessment showed that approximately $35 \%$ of the facilities would be incapable of handling the 125 -ton $\mathrm{R} / \mathrm{B}$ cask even if the modifications assessed were to be implemented. 


\section{Appendix A.}

\section{Summary of the Site Visit Program}




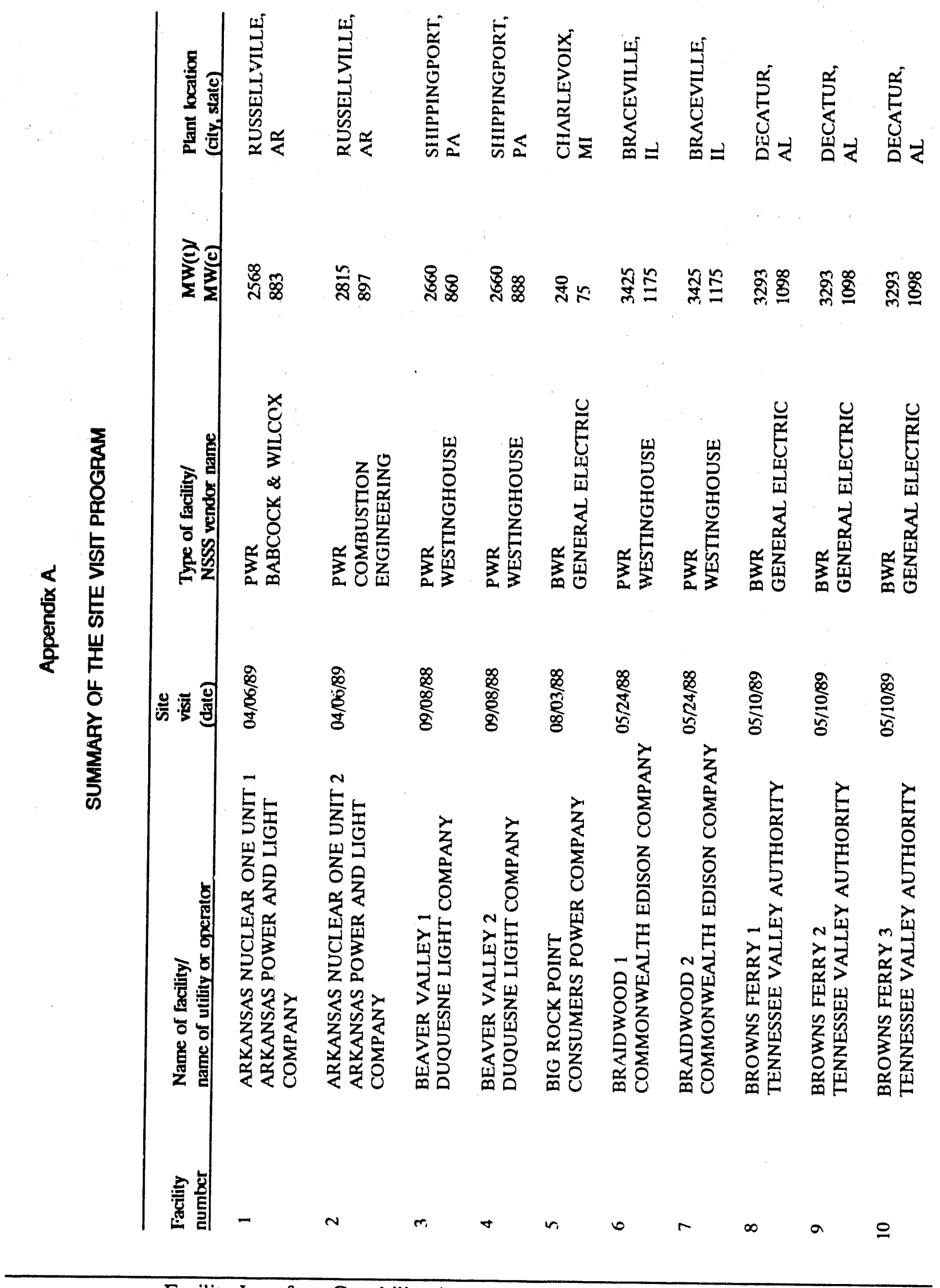

Facility Interface Capability Assessment (FICA) Summary Report 


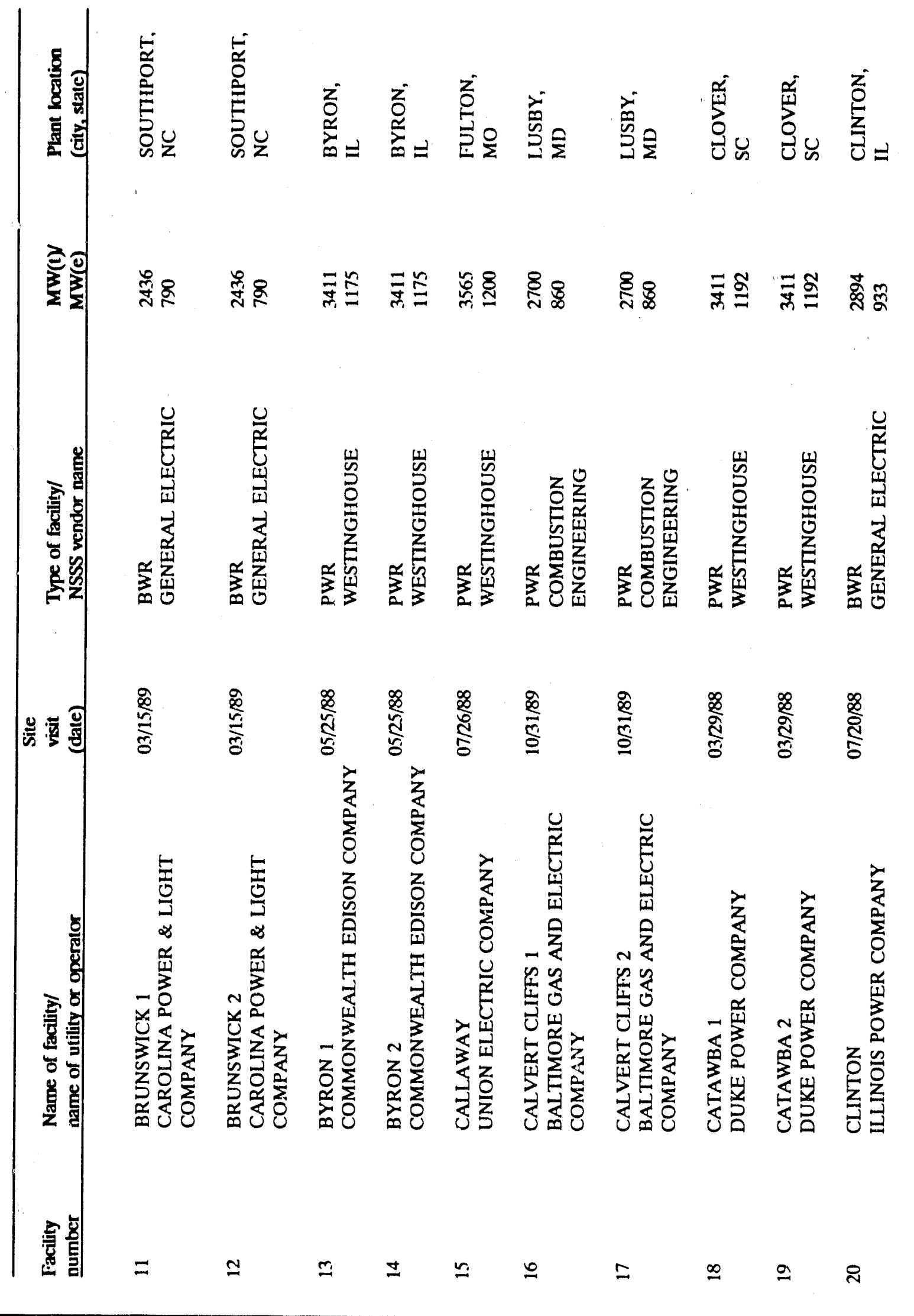

Facility Interface Capability Assessment (FICA) Summary Report 


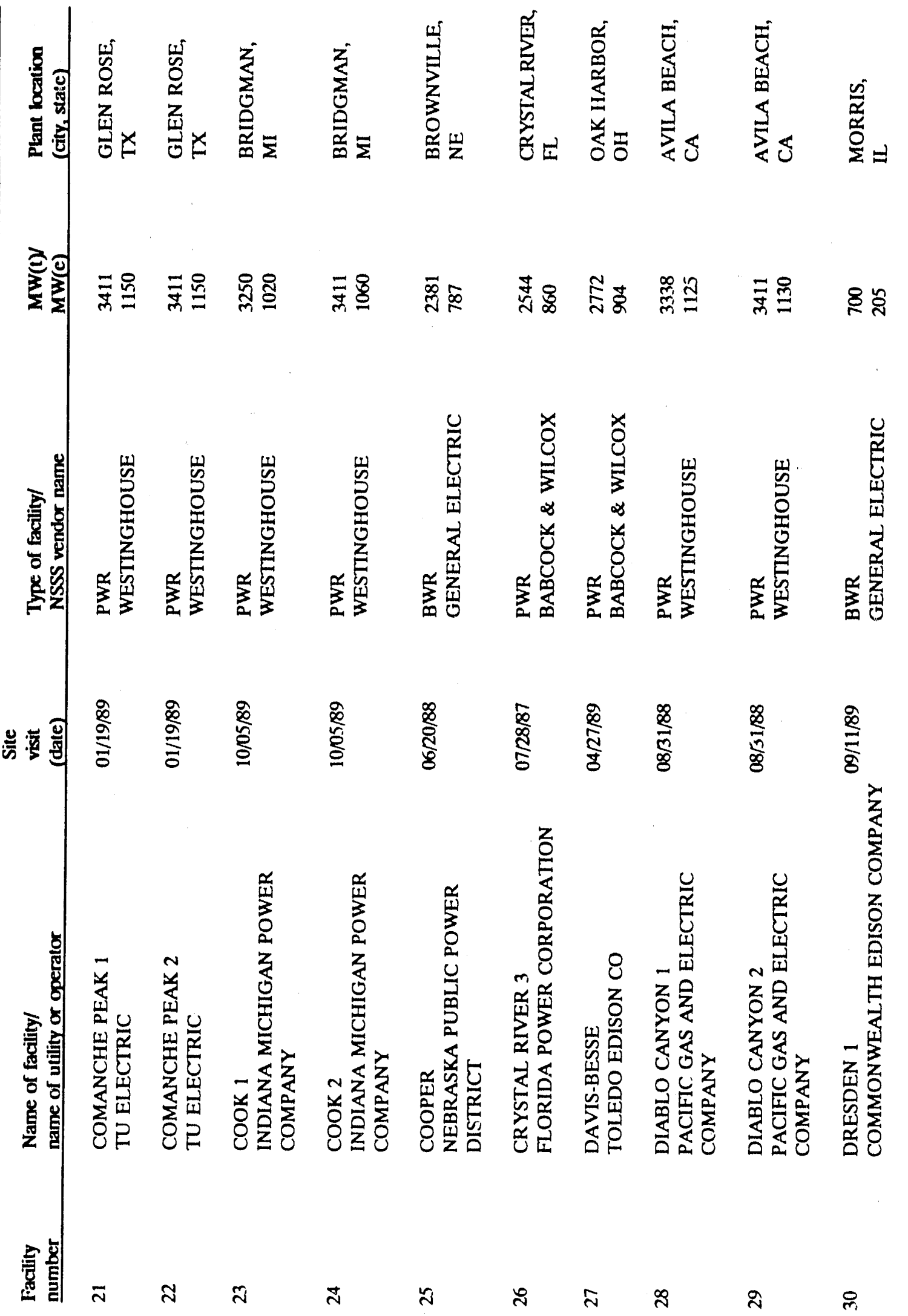

Facility Interface Capability Assessment (FICA) Summary Report 


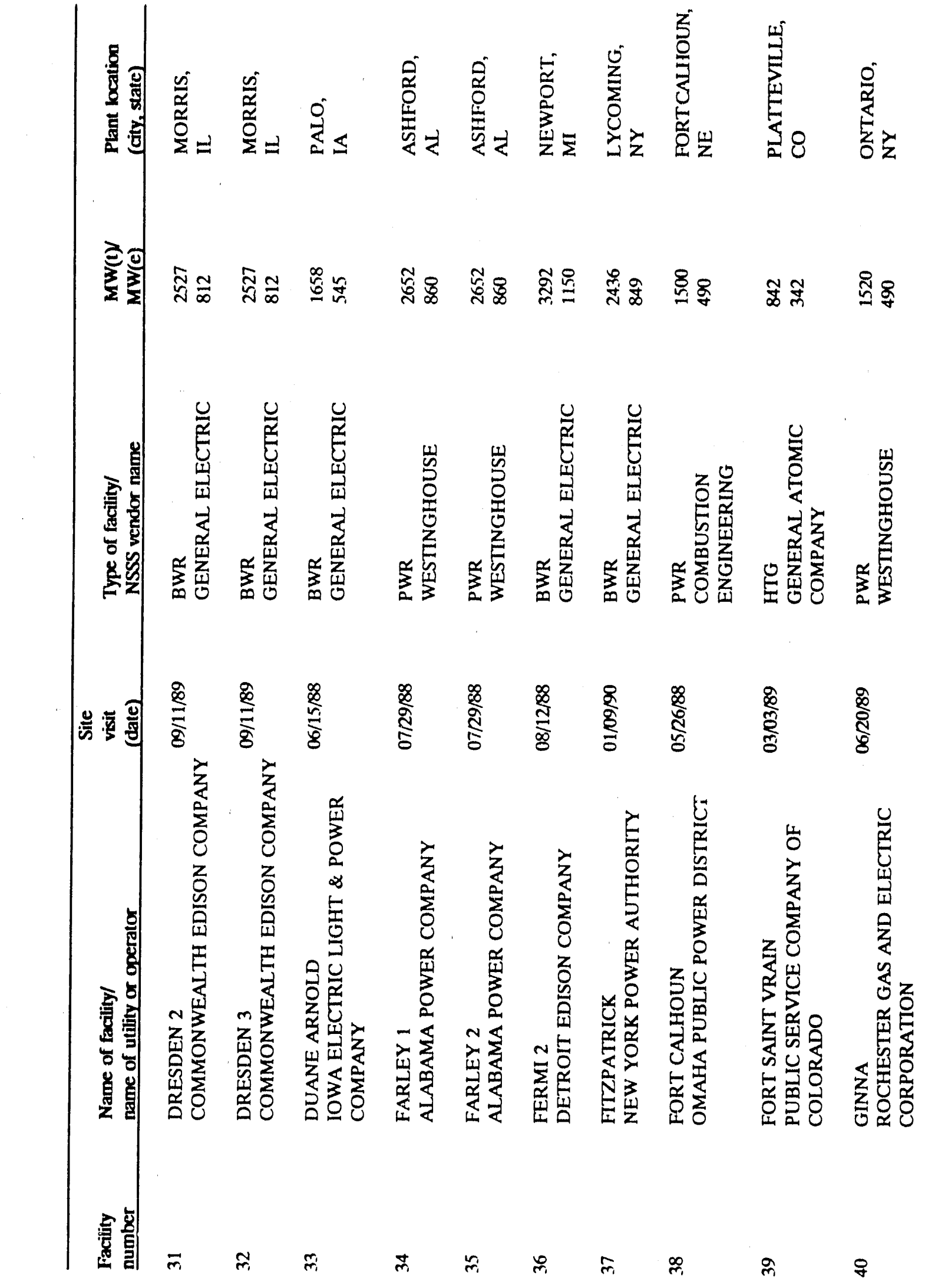

Facility Interface Capahility Assessment (FICA) Summary Report 


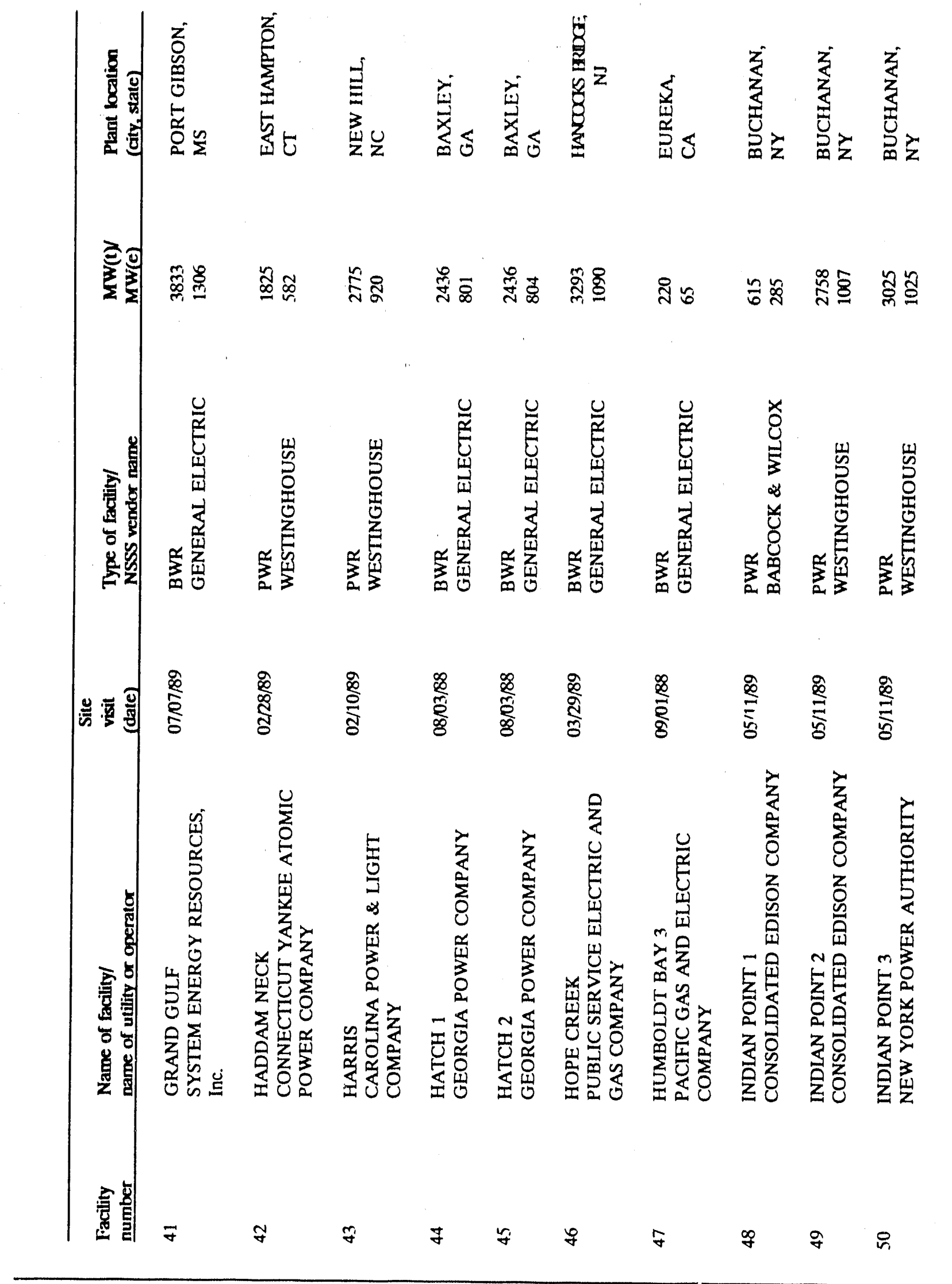

Facility Interface Capability Assessment (FICA) Summary Report 


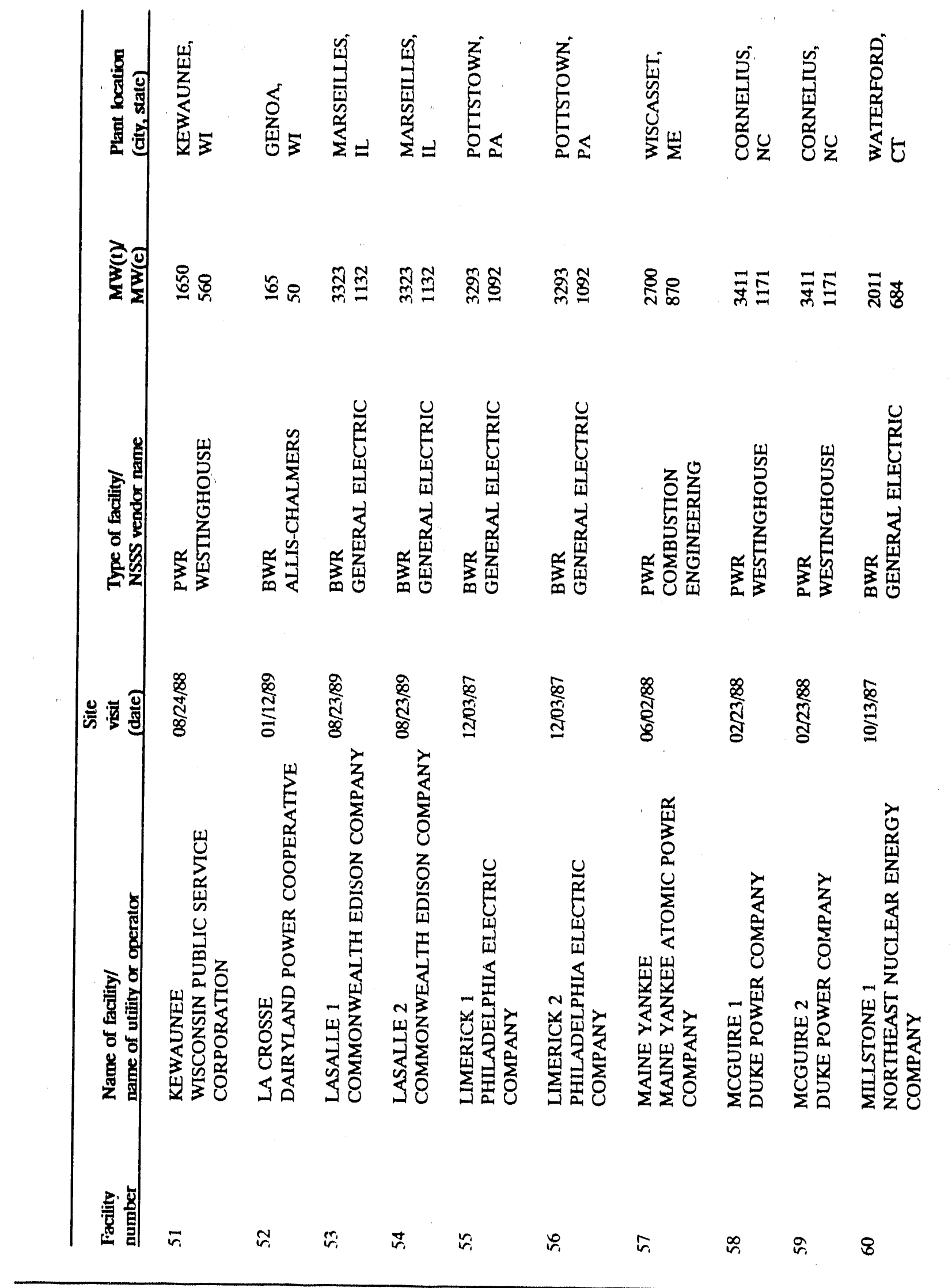

Facility Interface Capability Assessment (FICA) Summary Report 


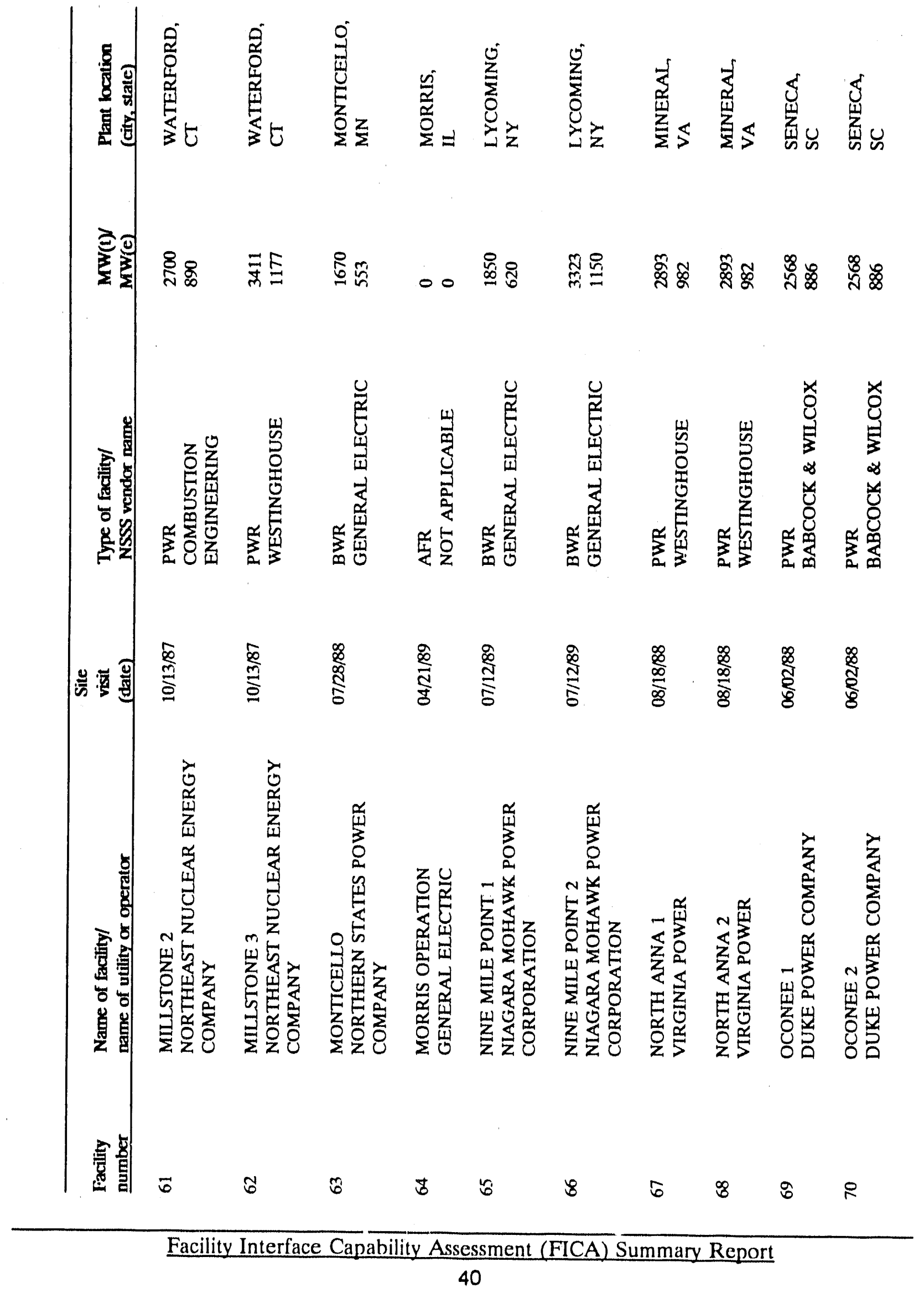




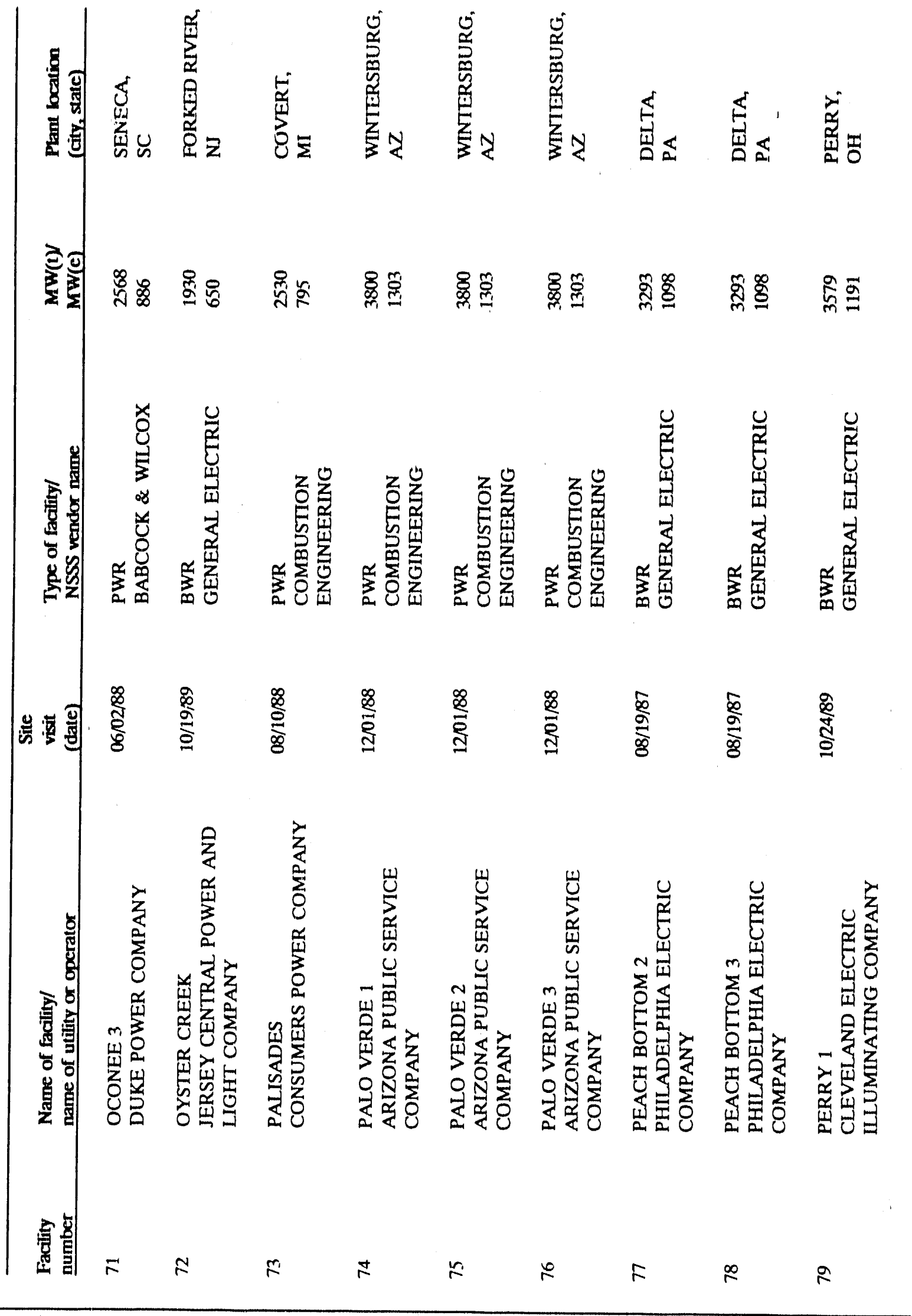

Facility Interface Capability Assessment (FICA) Summary Report 


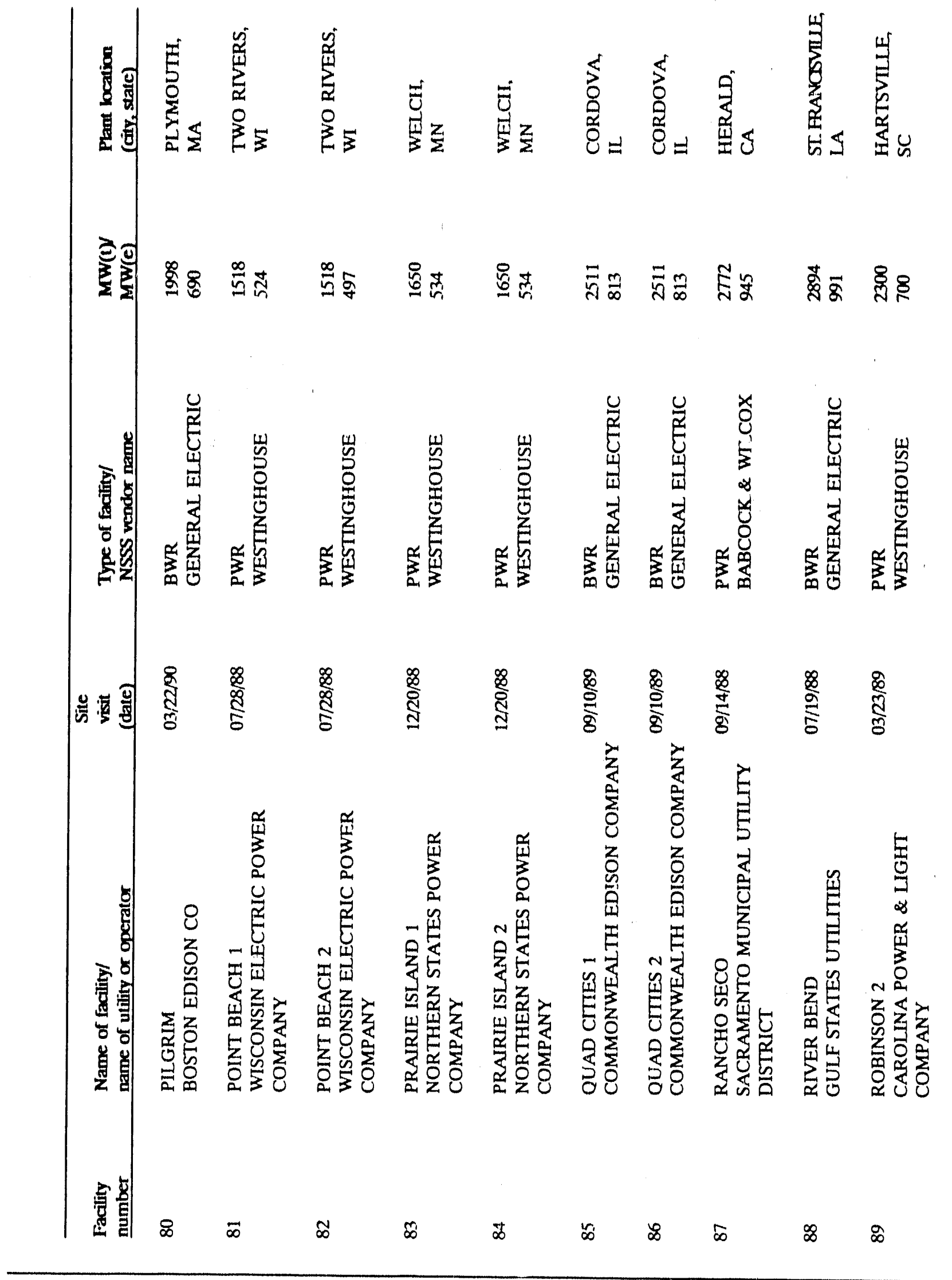

Facility Interface Capability Assessment (FICA) Summary Report 


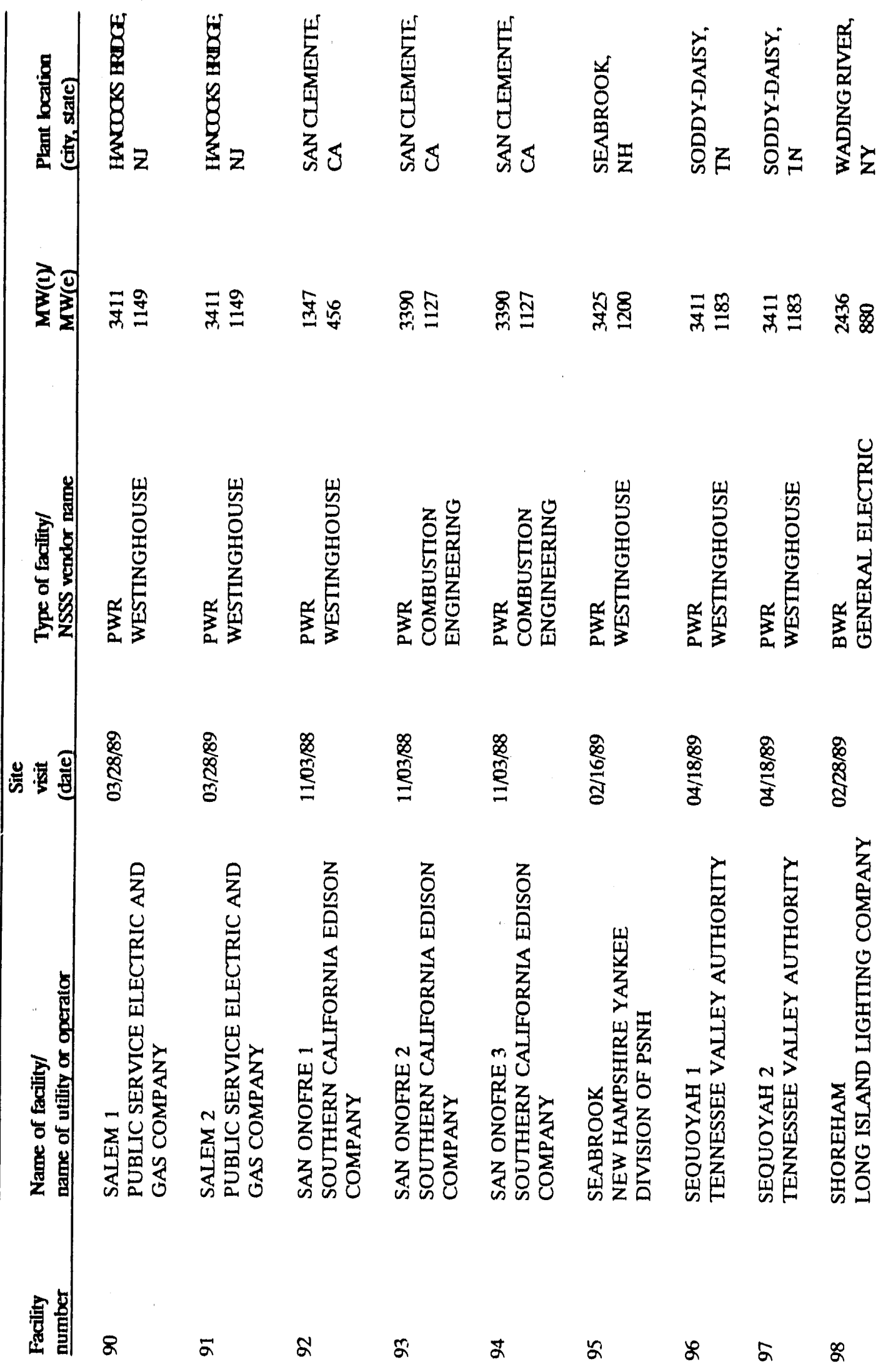

Facility Interface Capability Assessment (FICA) Summary Report 


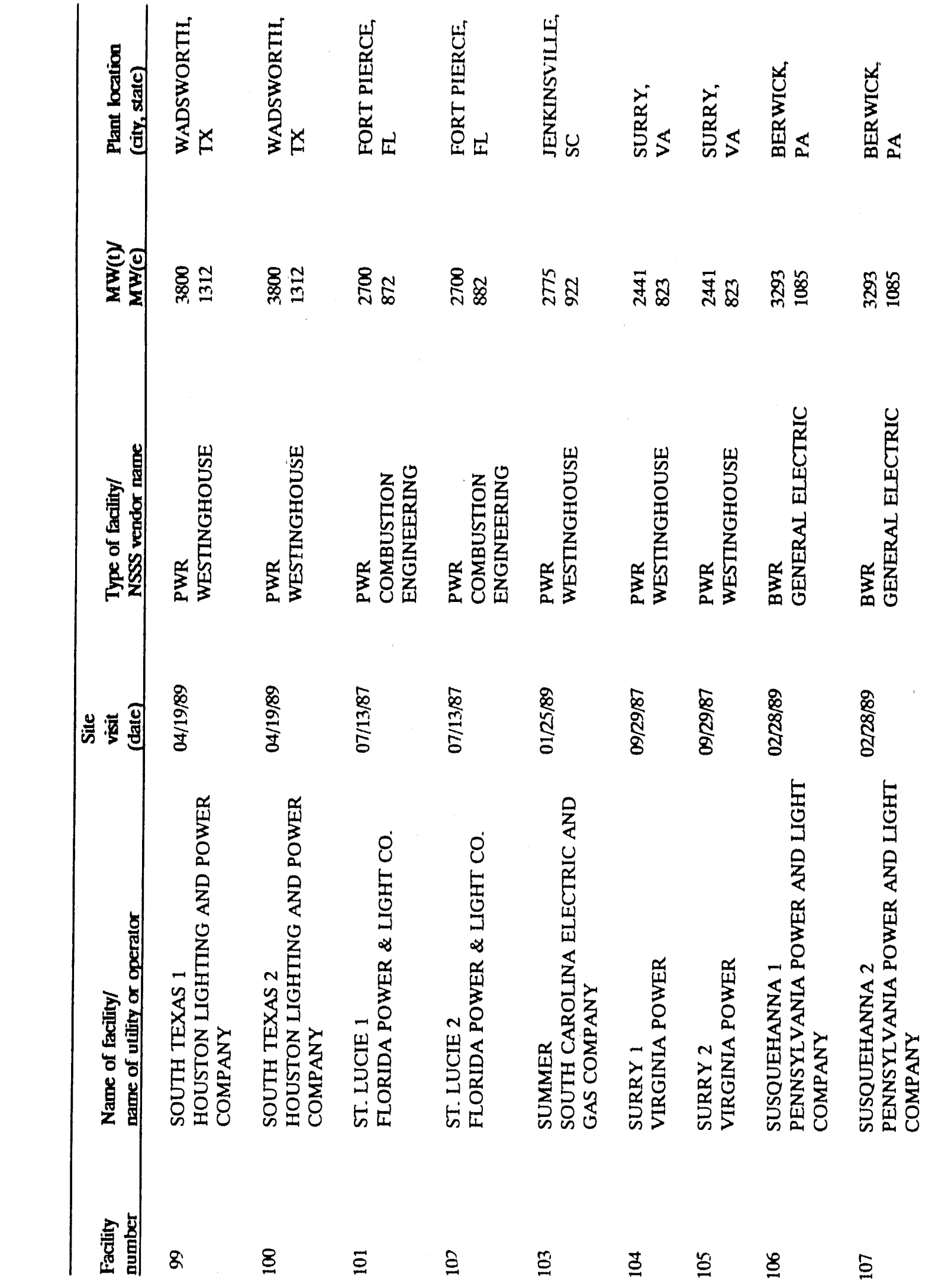

Facility Interface Capability Assessment (FICA) Summary Report 


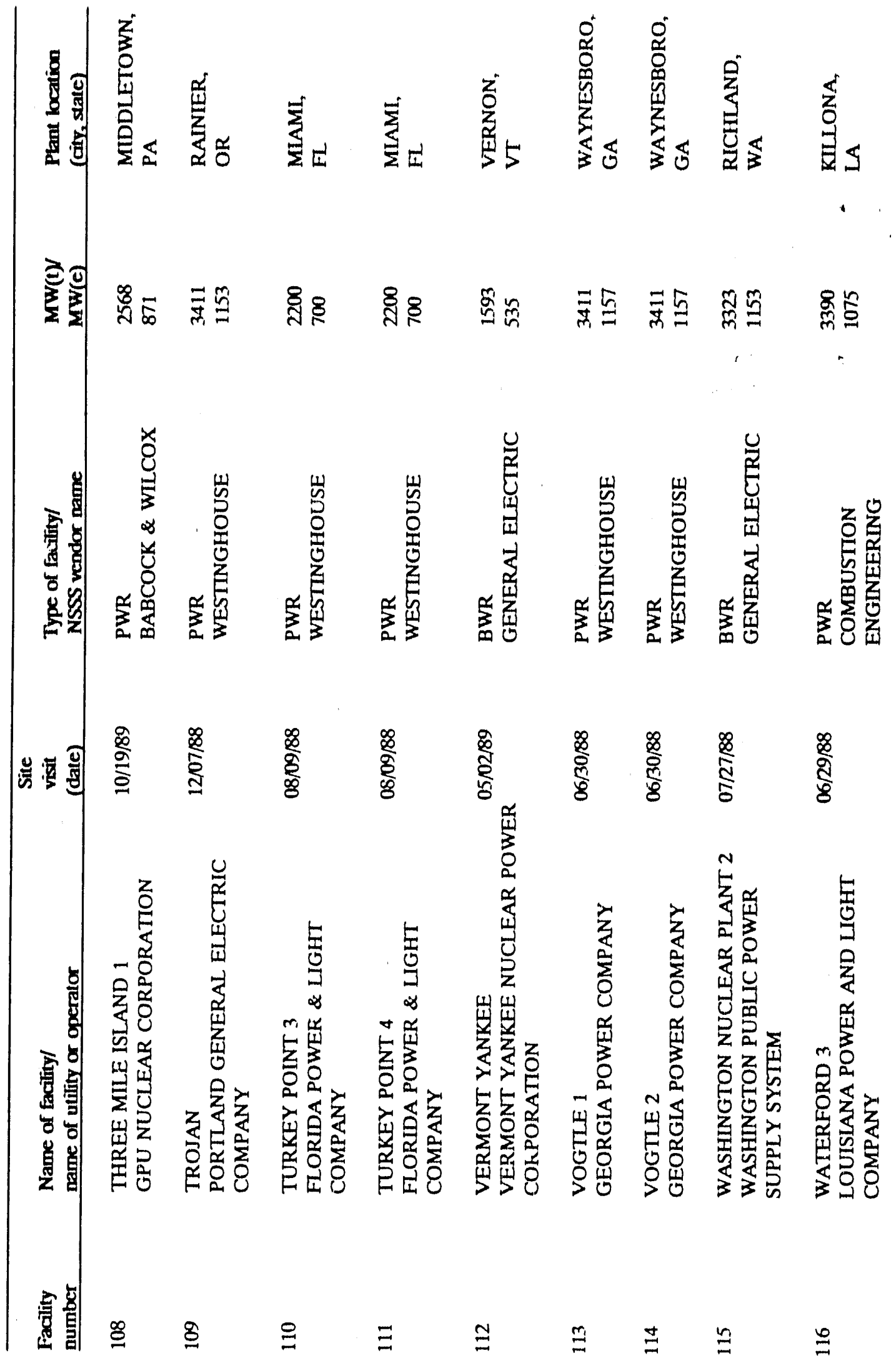

Facility Interface Capability Assessment (FICA) Summary Report 


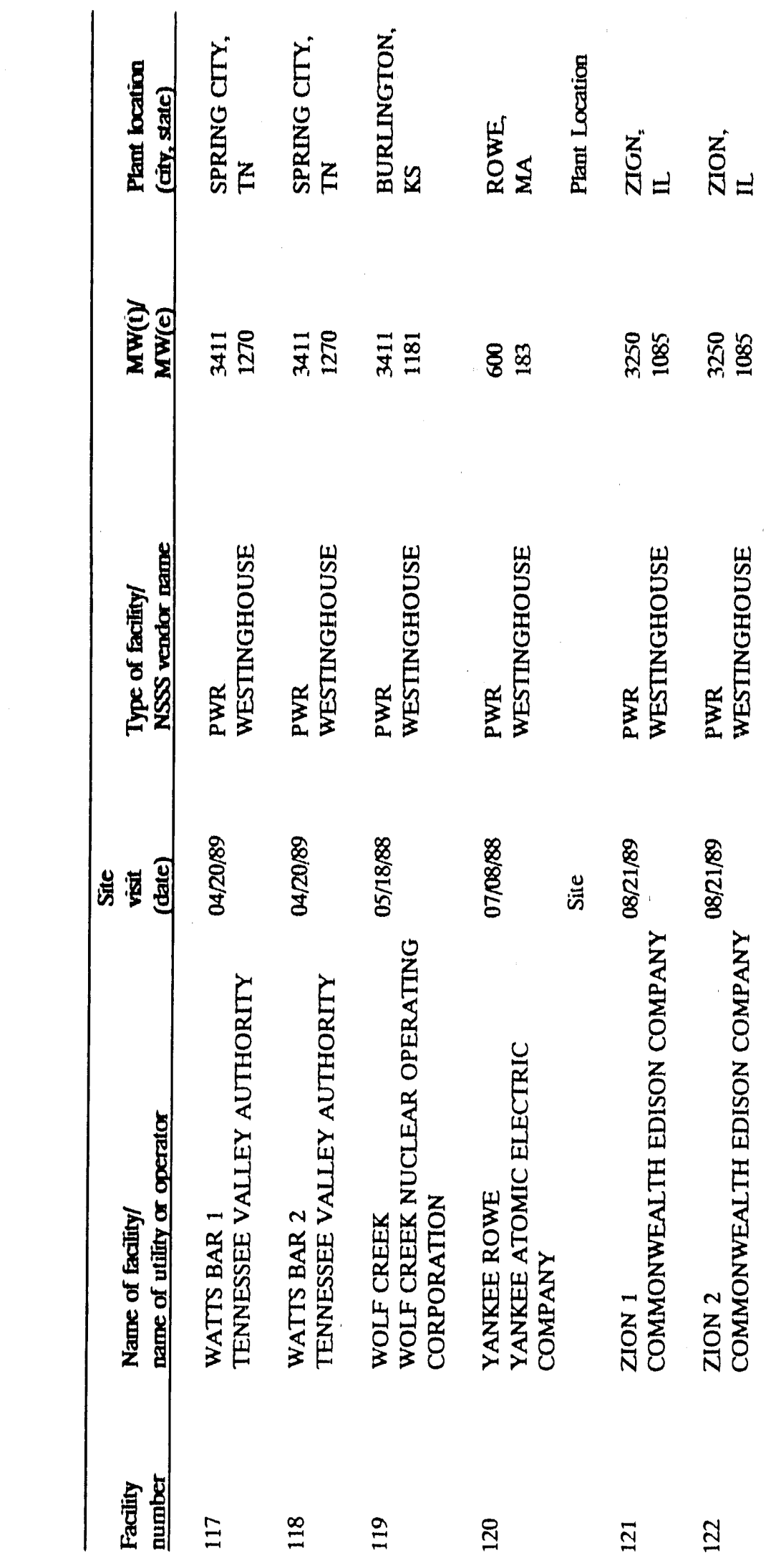

Facility Interface Capability Assessment (FICA) Surnmary Report 46 


\section{INTERNAL DISTRIBUTION}

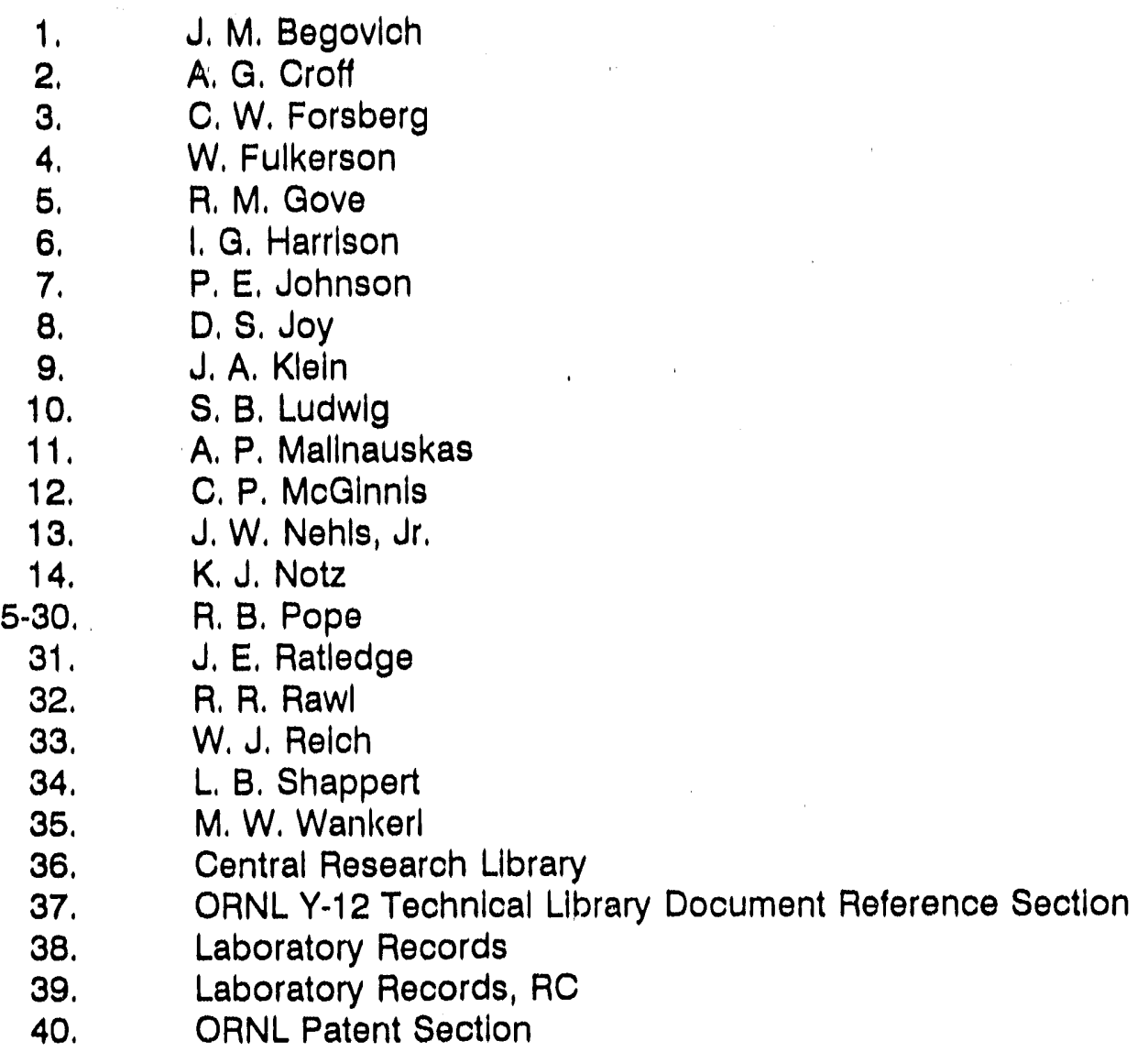

\section{EXTERNAL DISTRIBUTION}

41. Paul Adam, Wolf Creek Nuclear Operating Corp., Kansas Gas and Electric Co., P. O. Box 411, Burlington, KS 66839

42. Ken Allor, Baltimore Gas and Electric Co., P.O. Box 1475, Baltimore, MD 21203

43. C. K. Anderson, Nuclear Assurance Corporation, 6251 Crooked Creek Road, Norcross, GA 30092

44. Ray Baker, Georgla Power Co., P.O. Box 4545, Atlanta, GA 30302

45. L. Ball, DOE-ID, 785 DOE Place, Idaho Falls, ID 83402

46. Paul Ballinger, Nebraska Public Power District, P.O. Box 98, Brownville, NE 68321

47. John E. Barry, Gulf States Utilities, P.O. Box 2951, Beaumont, TX 77704

48. J. W. Bartlett, Office of Clvilian Radioactlve Waste Management, Department of Energy, Forrestal Building, 1000 Independence Avenue, SW, Washington, DC 20585.

49. E. J. Bentz, E. J. Bentz and Associates, 6090 Franconla Road, Alexandria, VA 22310

Facility Interface Capability Assessment (FICA) Summary Report 
50-51. R. E. Best, SAIC-OR, 301 Laboratory Road, P.O. Box 2501, Oak Ridge, TN 37831 2501

52. Gary Blair, Portland General Electric Co., 71760 Columbia River Highway, Ranier, OR 97048

53. P. Bolton, R. F. Weston, Inc., 955 L.Enfant Plaza, SW, 8th Floor, Washington, DC 20024

54. Mike Bourassa, Consumers Power Co., 10269 U.S. 31 North, Charlevioux, MI 49720

55. A. B. Brownstein, Office of Civilian Radioactive Waste Management, Department of Energy, Forrestal Building, 1000 Independence Avenue, SW, Washington, DC 20585.

56. John M. Burcheit, Yankee Atomic Electric Co., 1671 Worcester Road, Framington, MA 01701

57. C. Michael Callihan, Florida Power Corp, P.O. Box 219, Crystal River, FL 32629

58-63. B. M. Cole, TRW Environmental Safety Systems, Inc., 2650 Park Tower Drive, Suite 800, Vienna, VA 22180

64. J. H. Carlson, Office of Civilian Radioactive Waste Management, Department of Energy, Forrestal Building, 1000 Independence Avenue, SW, Washington, DC 20585

65. R. Chapman, EG\&G Idaho, P. O. Box 1625, Idaho Falls, ID 83415

66. John Closs, Northern States Power Co., 414 Nicollet Mall, Minneapolis, MN 55401

67. Amy C. Collinge, Philadelphia Electric Co., P.O. Box 8699, Philadelphia, PA 19101

68. M. J. Conroy, Office of Civilian Radioactive Waste Management, Department of Energy, Forrestal Building, 1000 Independence Avenue, SW, Washington, DC 20585

69. B. W. Coss, Texas Utilities Generating Co., 400 N. Olive St., LB-81, Dallas, TX 75201

70. Quersh Dahodwala, Public Service Electric and Gas Co., P.O. Box 236, MC-NC, Hancocks Bridge, NJ 08039

71. F. L. Danese, SAIC-OR, 301 Laburatory Road, P.O. Box 2501, Oak Ridge, TN 37831-2501

72. L. M. Dawson, TRW Environmental Saíety Systems, Inc., 2650 Park Tower Drive, Suite 800 , Vienna, VA 22180

73. J. Doman, R. F. Weston, Inc., 955 L.Enfant Plaza, SW, 8th Floor, Washington, DC 20024

74. F. Emami, TRW Environmental Safety Systems, Inc., 2650 Park Tower Drive, Suite 800, Vienna, VA 22180

75. Tommy Errington, Entergy Operations, Inc., Mississippi Power and Light Co., P. O. Box 756, Port Gibson, MS 39150

76. John L. Etheridge, Louisiana Power and Light Co., P.O. Box 60340, New Orleans, LA 70160

77. M. Fisher, DOE-ID, 785 DOE Place, Idaho Falls, ID 83402

78. Anton A. Fuierer, Rochester Gas and Electric, Corp., 89 East Avenue, Rochester, NY 14649

79. Patricia J. Garnier, Communwealth Edison Co., 1400 Opus Place, Suite 400, Downers Grove, IL 60515 
80. R. Hahn, R. F. Weston, Inc., 955 L.Enfant Plaza, SW, 8th Floor, Washington, DC 20024

81. K. Henry, EG\&G Idaho, P.O. Box 1625, Idaho Falls, ID 83415

82. P. F. Highberger, TRW Environmental Safety Systems, Inc., 2650 Park Tower Drive, Suite 800 , Vienna, VA 22180

83. C. V. Hill, SAIC-OR, 301 Laboratory Road, P.O. Box 2501, Oak Ridge, TN 378312501

84. Gene Ingels, Morris Operations, GE Nuclear Energy, 7555 E. Collins Road, Morris, IL 60450

85. E. Johnson, TRW Environmental Satety Systems, Inc., 2650 Park Tower Drive, Sulte 800 , Vienna, VA 22180

86. R. H. Jones, P.O. Box 1510, Los Gatos, CA 95030

87. Taj Khan, Sacramento Municipal Utility District, 14440 Twin Cities Road, Herald, CA 95638

88. M. J. Klimas, DOE-CH, 9800 South Cass Avenue, Argonne, IL 60439

89. Dan D. Klooch, Omaha Public Power District, 1623 Harvey St., Omaha, NE 68102

90-93. S. P. Kraft, EEI, 1111 19th St, NW, Washington, DC 20036

94. G. Konzek, Battelle Pacific Northwest Laboratory, P.O. Box 999, Richland, WA 99352

95. Robert K. Kunita, Carolina Power \& Light Co., P.O. Box 1551, Raleigh, NC 27602

96. Dr. James W. Kutcher, Cleveland Electric Illuminating Co., Toledo Edison Co., 300 Madison Ave., Toledo, $\mathrm{OH} 43652$

97. $\quad W^{\prime}$. H. Lake, Office of Civilian Radioactive Waste Management, Department of 'energy, Forrestal Building, 1000 Independence Avenue, SW, Washington, DC 20585

98-101. R. Lambert, EPRI, 3412 Hillview Ave, Palo Alto, CA 94303

102. David L. Larkin, Washington Public Power Supply System, P.O. Box 968, Richland, WA 99352

103. Sharon L. Lawison, Arizona Public Service Co., P.O. Box 52034, Station 7434, Phoenix, AZ 85072

104. K. H. Lee, Nuclear Assurance Corporation, 6251 Crooked Creek Road, Norcross, GA 30092

105. Eric Lewis, Indiana Michigan Power Co., American Electric Power Co., P.O. Box 16631, Columbus, UH 43216

106. Robert W. Lorenz, Pacific Gas and Electric Co., 77 Beale St., Rm 1412, San Francisco, CA 93424

107. R. E. Luna, Sandia National Laboratories, P.O. Box 5800, Albuquerque, NM 87185

108-112. R. R. MacDonald, TRW Environmental Safety Systems, Inc., 2650 Park Tower Drive, Suite 800, Vienna, VA 22180

113. J. T. Mayer, TRW Environmental Safety Systems, Inc., 2650 Park Tower Drive, Suite 800, Vienna, VA 22180

114. R. McKee, Battelle Pacific Northwest Laboratory, P.O. Box 999, Richland, WA 99352

115. W. Mings, DOE-ID, 785 DOE Place, Idaho Falls, ID 83402

116. N. B. McLeod, TRW Environmental Safety Systems, Inc., 2650 Park Tower Drive, Suite 800 , Vienna, VA 22180

Facility Interface Capability Assessment (FICA) Summary Report 
117. H. Michael Metell, Vermont Yankee Nuclear Power Corp., RD 5, P.O. Box 169, Brattleboro, VT 05301

118. R. A. Milner, Office of Civilian Radioactive Waste Management, Department of Energy, Forrestal Building, 1000 Independence Avenue, SW, Washington, DC 20585

119-123. N. Mote, Nuclear Assurance Corporation, 6251 Crooked Creek Road, Norcross, GA 30092

124. Bob Mullin, Tennessee Valley Authority, Blue Ridge PI., 1101 Market St., Chattanooga, TN 37401

125. Paul D. Myers, Southern California Edison Co., P.O. Box 800, Rosemead, CA 91770

126. S. E. Nichols, Maine Yankee Atomic Power Co., Edison Drive, Augusta, ME 04330

127. Dr. Walter C. Nodean, lowa Electric and Power Co., P.O. Box 351, Cedar Rapids, IA 52406

128. D. Nolan, TRW Environmental Safety Systems, Inc., 2650 Park Tower Drive, Suite 800, Vienna, VA 22180

129. Alan C. Passwater, Union Electric Co., P.O. Box 149 M/S-470, St. Louis, MO 63166

130. F. G. Peters, Office of Civilian Radioactive Waste Management, Department of Energy, Forrestal Building, 1000 Independence Avenue, SW, Washington, DC 20585

131. R. W. Peterson, E. J. Bentz and Associates, 6090 Franconia Road, Alexandria, VA 22310

132. Frank Philpott, Arkansas Power and Light Co., Route 3, P.O. Box 137 G, Russellville, AR 72801

133. John J. Piascik, Boston Edison Co., 25 Braintree Hill Park, Braintree, MA 02184

134-145. T. Pollog, Office of Civilian Radioactive Waste Management, Department of Energy, Forrestal Building, 1000 Independence Avenue, SW, Washington, DC 20585

146. Daniel J. Ropson, Wisconsin Public Service Corp., P.O. Box 19002, Green Bay, WI 54307

147. Dr. Seymour J. Raffety, Dairyland Power Cooperative, P.O. Box 275, Genoa, WI 54632

148. M. Rahami, R. F. Weston, Inc, 955 L.Enfant Plaza, SW, 8th Floor, Washington, DC 20024

149. Robert Rasmussen, Duke Power Co., P.O. Box 33189, Charlotte, NC 28242

150. Richard Remshaw, Consolidated Edison of New York, 4 Irving Place, Room 1250-

S, New York, NY 10003

151. G. K. Rhode, Niagara Mohawk Power Corp., 301 Plainfield Rd., Syracuse, NY 13212

152. M. D. Rickles, Alabama Power Co., P.O. Box 2641, Birmingham, AL 35261

153. J. B. Roberts, DOE-CH, 9800 South Cass Avenue, Argonne, IL 60439

154. T. Sanders, Sandia National Laboratories, P.O. Box 5800, Albuquerque, NM 87185

155. S. P. Schmid, SAIC-OR, 301 Laboratory Road, P.O. Box 2501, Oak Ridge, TN 37831-2501

156. Sheldon I. Schreiner, Long Island Lighting Co., P.O. Box 1, Wading River, NY 11719

Facility Interface Capability Assessment (FICA) Summary Report 
157. Robert D. Sherer, Duquense Light Co., 301 Grant St., Pittsburgh, PA 15279

158. Steve Sherrow, Public Service Company of Colorado, P.O. Box 840, Denver, CO 80651

159. Addison D. Smart, Detroit Edison Co., 6400 North Dixie Highway, Newport, MI 48166

160. Marvin L. Smith, Virginia Power, 5000 Dominion Blvd., Glen Allen, VA 23060

161. S. Smith, Office of Civilian Radioactive Waste Management, Department of Energy, Forrestal Building, 1000 Independence Avenue, SW, Washington, DC 20585

162. Frank Spangenburg, Illinois Power Co., P.O. Box 678, Clinton, IL 61727

163. Walter B. Sturgeon, Jr., New Hampshire Yankee Division of Public Service, P. O. Box 300, Seabrook, NH 03874

164. B. R. Teer, TRW Environmental Safety Systems, Inc., 2650 Park Tower Drive, Suite 800, Vienna, VA 22180

165. T. Tehan, Pacific-Nuclear Systems, Inc., 7555 E. Collins Rd., Morris, IL 60450

166. C. S. Thorup, Nuclear Assurance Corporation, 6251 Crooked Creek Road, Norcross, GA 30092

167. Gerry P. Van Noordennen, Connecticut Yankee Atomic Power Co., P.O. Box 270, Hartford, CT 06141

168. Howard R. Vernick, Pennsylvania Power and Light Co., Two North Ninth St., Allentown, PA 18101

169. J. M. Viebrock, Nuclear Assurance Corporation, 6251 Crooked Creek Road, Norcross, GA 30092

170. John A. Vincent, GPU Nuclear Corp., One Upper Pond Road, Parsippany, NJ 07054

171. Douglas Warner, South Carolina Electric and Gas Co., Columbia, SC 29218

172. R. Williams, EPRI, 3412 Hillview Ave, Palo Alto, CA 94303

173. J. R. Worden, Houston Lighting and Power Co., P. O. Box 1700, Houston, TX 77001

174. H. Worle, DOE-ID, 785 DOE Place, Idaho Falls, ID 83402

175. William R. Yario, New York Power Authority, 123 Main St., White Plains, NY 10601

176. David Zabransky, Wisconsin Electric Power Co., 231 W. Michigan St., P.O. Box 2046, Milwaukee, WI 53201

177. George T. Zamry, Florida Power and Light Co., P. O. Box 14000 M/S JMM-JB, Juno Beach, FL 33408

178. Office of Assistant Manager, Energy Research and Development, DCE-OR, P. O. Box 2001, Oak Ridge, TN 37831

179-188. Office of Scientific and Technical Information, P.O. Box 68, Oak Ridge, TN 37831

Facility Interface Capability Assessment (FICA) Summary Report 

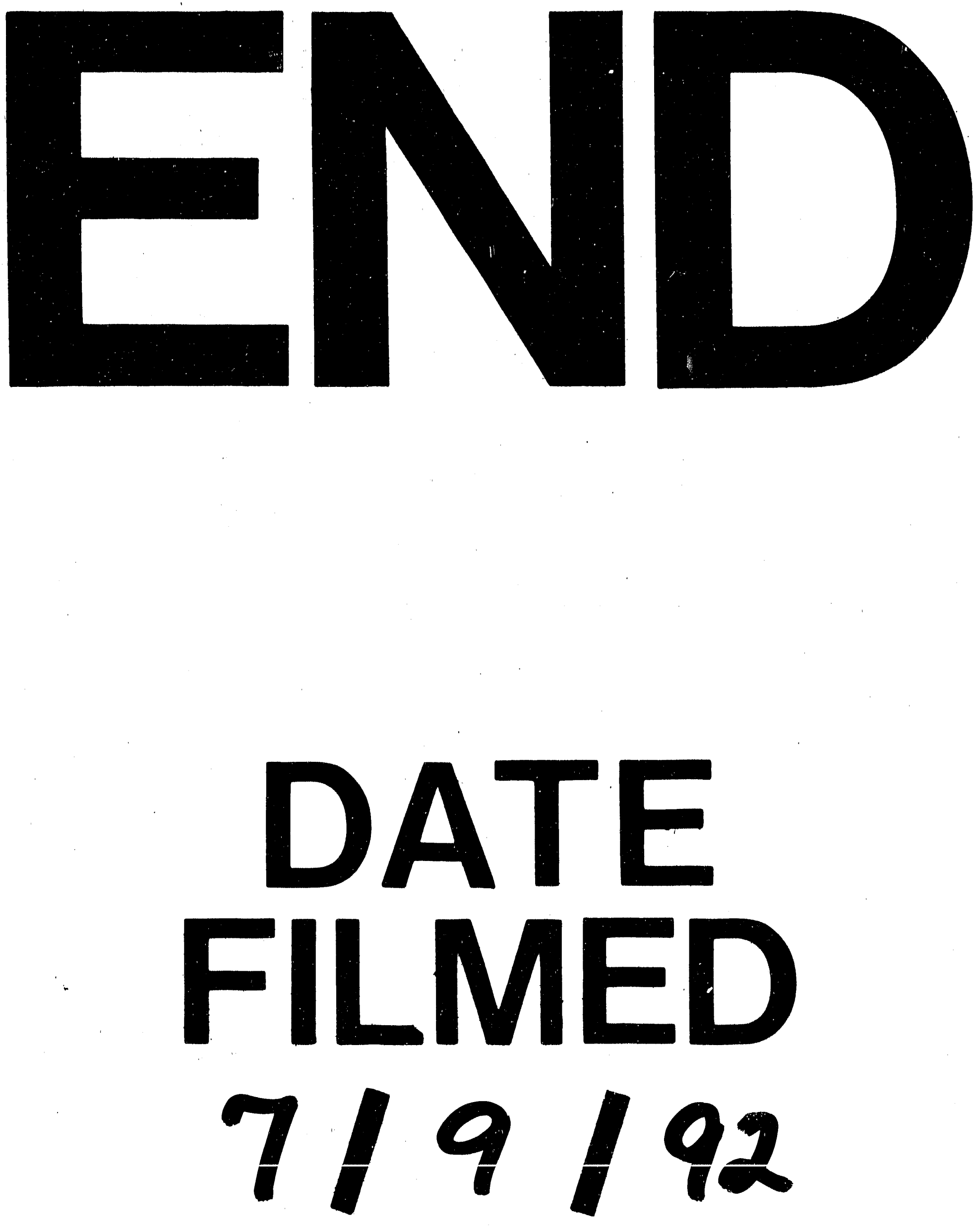
- 